\title{
第32回日本老年医学会総会一般演題（IV）
} $\begin{array}{rll}\text { 座長 : 上田 } & \text { 一雄, 大井 } \quad \text { 玄, 江藤 } \\ \text { 木畑 } & \text { 正義, 山之内 } & \text { 博, 萬年 }\end{array}$

266. 地域における65歳以上老人の検診成績から 一長寿要因の検討一

杏林大衛生 古見 耕一, 角田 透 照屋 浩司, 竹前 健彦

立川共済病院内科

森盿祐, 金子厚

目的：到来する高龄化社会への対応として“健やか に老い活気にみちた老後を”などが叫ばれ，国をはじ め多くの地域で種々の対策が展開されている。このよ らな現状下で健やかに老いるための要件の検討は重要 な課題の一つである。私どもは長年にわたり活気にみ ちた老人が多く比較的長寿者がみかけられる沖縄県佐 敷町において住民の健康づくり活動に協力してきた。 今回は同町における住民検診結果から65歳以上老人の 成績について, 過去 7 年間の死亡者と生存者との比較 を行らことにより長寿要因の検討を試みた。

方法：同町に打いて昭和 58 年 1 月から平成元年 12 月 までの 7 年間に死亡した者のうち，男では65歳以上 75 歳未満 17 人, 75 歳以上 22 人, 女では 65 歳以上 80 歳未満 30 人， 80 歳以上 17 人を死亡者群とし，昭和 56 年の時点 で生存者男 65 歳以上 75 歳未満 122 人, 75 歳以上 68 人, 女 65 歳以上 80 歳未満 265 人, 80 歳以上 30 人を生存者群とし て, 両群の昭和 56 年度検診成績を比較検討した。検討 した項目は肥満度, 血圧, 総コレステロール, HDL・ コレステロール，総蛋白質，アルブミン，過酸化脂質， ビタミン $\mathrm{E}$ ，尿酸等である.

結果：検討した項目のらち死亡, 生存との関連が示 唆されたのは肥満度, 血圧, 総コレステロール, 過酸 化脂質，ビタミン $\mathrm{E}$ 等であった。 とくに総コレステ ロールは男で 65 歳以上 75 歳未満, 女で65歳以上 80 歳未 満の前期老齢死亡者群で低值であった。すなわち男女 各死亡者群, 生存者群は, それぞれ $159.7 \pm 28.4 \mathrm{mg} / \mathrm{d} l$, $176.4 \pm 35.8 \mathrm{mg} / \mathrm{d} l, 178.2 \pm 26.8 \mathrm{mg} / \mathrm{d} l, 195.0 \pm 34.8$ $\mathrm{mg} / \mathrm{d} l$ であった. ビタミン $\mathrm{E}$ も前期老战死亡者群で低 い傾向がみられた。男の死亡者群, 生存者群のそれは, $0.84 \pm 0.47 \mathrm{nmol} / \mathrm{ml}, 0.91 \pm 0.41 \mathrm{nmol} / \mathrm{ml}$ で,女はそ れぞれ $1.08 \pm 0.56 \mathrm{nmol} / \mathrm{m} l, 1.13 \pm 0.66 \mathrm{nmol} / \mathrm{m} l$ で あった。今回の検討から死亡者群のデータがさらに集
文夫, 簛野 脩一, 長谷川恒雄, 山本 俊幸, 佐藤 秩子 徹, 道場 信孝, 西尾一郎, 東儀 英夫, 内藤 周幸

積されることによって，より確かな長寿要因が抽出さ れるものと考壳られた。

\section{7. 循環器疾患の危険因子に対する地域差につい} $\tau$

\section{九州中央病院内科}

梁井 俊郎, 坪田 順昭, 武谷 溶 成人日本人の死因に占める循環器疾患の割合は大き いが，その死亡率は地域差が認められる。公立学校共 済組合員を対象とした人間ドックの成績を基に, 循環 器疾患の地域差を九州 8 県（沖縄を含む）について検 討した.

方法：昭和62年度に30歳から60歳の公立学校共済組 合員と任意継続 (退職者)の人を含め男女計4,694名を 対象として人間ドックの検診を実施した. 今回の分析 は現職の男性40歳から59歳である。検診項目のらち， 血圧值, 糖尿病, 肥満, 総コレステロール值, 中性脂 肪を中心に分析を行なった。血圧值は安静後 5 分後の 座位血圧(自動血圧測定)，糖尿病は $75 \mathrm{~g}$ OGTT 試験の 成績をWHOの基準に準拠して判定した。総コレステ ロール, 中性脂肪は酵素法で測定し, 肥満は Quetelet index $\geqq 25.4$ とした.

成績 : WHO 基準による高血圧の頻度は $17 \%$ 前後で 九州 7 県と沖縄県では差がなかった。高コレステロー ル血症の頻度も $30 \%$ 前後と高血圧と同様に地域差はみ られなかった。中性脂肪 $150 \mathrm{mg} / \mathrm{d} l$ 以上の頻度は沖縄 県で $38 \%$ と高く, 福岡県を除く九州各県と比べ有意に 高い頻度を示した。 WHO 基準による糖尿病の頻度を 比較すると九州各県が $7 \%$ 前後であるのに対して沖縄 県では13.6\%であり, 九州各県と比較して有意に高頻 度であった。糖尿病に関係する肥満の頻度を比較した。 Quetelet index 25.4以上（箕輪の標準体重表で $120 \%$ 以 上）を肥満とすると九州 7 県は $25 \%$ 以下であるのに対 して沖縄県では $38 \%$ と高頻度でありこれも九州各県と 比較して有意に高い頻度であった。今後は九州管内の 循環器疾患別の risk profile と予後の関係を検討する 予定である。 
268. 成人病危険因子の検討一東京都檜原村住民検 診10年間の検討から一

埼玉医大神経内科

金子厚

立川共済病院内科

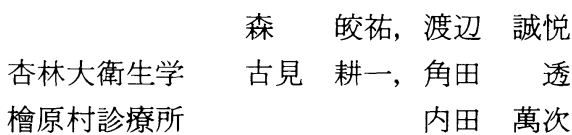

目的：我々は以前より地域特性を重視した疫学調查 を通じ脳卒中の発症, 死亡に関わる一連の検討を行っ てきた。今回は成人病一般の地域特性について述べる と共に，その疾病と諸因子の時代的変遷について報告 する。

方法と対象：調査は東京都檜原村の40歳以上の住民 検診者を対象とし，昭和56年から平成 2 年までの 10 年 間，年 1 回の巡回方式で行った。同村の死亡統計の検 討と受診者の追跡調查を行い，検診成績と比較した.

結果：平成元年現在人口 3,961 人, 年次平均受診者数 361.5 人であった. 10 年間で老齢人口比率の増加がみら れた。受診者年龄はほぼ不変であったが，検診成績で は有意の収縮期血圧の低下と血清総コレステロールの 上昇を認めた。一方で，死亡率は脳血管障害の横ばい ないし低下傾向，虚血性心疾患の増加傾向を認めた。

老年医学的意義：老齢者人口が増加傾向にある山村 での住民検診を通じて成人病の発症因子，とくに生活 習慣について検討を加えた。

\section{9. 老人健診結果に基づく動脈硬化危険因子の検} 討

結核予防会千葉県支部

角南 祐子, 志村 昭光

千葉大第三内科 増田 善昭, 稲垣 義明

目的：農村部の県と都市部の都府県の健診成績を比 較した報告は多くみらけるが，同一県下の地域間で比 較検討した報告は少ない、今回，同一県下の都市部， 漁村部, 農村部の老人健診結果をもとに，今後の健康 指導の参考にするため, 動脈硬化関連検査値の性, 年 齢扔よび地域差を比較し，検討を加えたので報告する。

対象拉よび方法：昭和 62 年度老人健診を受診した都 市部住民4,434名，漁村部住民2,338名，農村部住民 2,687 名，合計 9,509 名を対象とし，動脈硬化の危険因 子のうち, 血圧, 肥満度, 総コレステロール值の平均 値を性，年歯令，地域別に求め比較検討した。

結果：収縮期血圧は女性に比し男性のほうが高く, 男女とも加龄とともに高くなり，漁村，農村部は都市
部に比し有意に高かった。拡張期血圧は女性に比し男 性のほらがやや高く, 男女とも有意な年齢差は認めら れず, 地域差をみると農村部, 漁村部, 都市部の順に 高かった，肥満度は男性に比し女性の注らが高く，男 性では有意な地域差は認められなかったが，女性では 漁村部に比し農村部, 都市部で有意に高かった。総コ レステロール値は男性に比し女性のほうが高かった. 女性では40歳台に比し50歳台以上で有意に高く, 都市 部は漁村，農村部に比し有意に高値であった。次いで 日常の測定の容易な肥満度と血圧, 総コレステロール 值の関係をみた。肥満度 $20 \%$ 以上の肥満群と $10 \%$ 未満 の非肥満群で, 収縮期血圧 $160 \mathrm{mmHg}$ 以上, 挔張期血圧 $95 \mathrm{mmHg}$ 以上, 総コレステロール值 $220 \mathrm{mg} / \mathrm{d} l$ 以上の 出現率を比較したところ，漁村，農村部の全年歯層と 都市部の 40, 50歳台では, 非肥満群に比し肥満群で拡 張期血圧 $95 \mathrm{mmHg}$ 以上, 総コレステロール值 $220 \mathrm{mg} /$ $\mathrm{d} l$ 以上の出現率が高い傾向が認められた。

考案：漁村, 農村部では高血圧予防，都市部では高 コレステロール血症予防が重要であり, 肥満予防は双 方の予防につながるといえよう。

\section{0. 空腹時血糖值と生命予後：久山町研究} 九州大第二内科

$\begin{array}{lrrrr}\text { 加藤 } & \text { 功, 上田 } & \text { 一雄, 蓮尾 } \text { 裕 } \\ \text { 清原 } & \text { 裕, 河野 } & \text { 英雄, 大村 } & \text { 隆夫 } \\ \text { 新川 } & \text { 淳, 岩本 } & \text { 廣満, 中山 } & \text { 敬三 } \\ \text { 藤島 } & \text { 正敏 } & & & \end{array}$

目的：本邦に扔いて，空腹時血糖値（以下 FBS）に 特に注目して，それと生命予後との関係を一般住民に ついて詳細に分析した報告はない、今回私どもは, 最 近の久山町住民を対象に断面調查時の FBS と追跡調 査に拈ける総死亡や心血管系疾患死亡との関連につい て検討した。

方法：1978年に満40歳以上の久山町全住民を対象に 成人病検診を扎こない, 対象の $82.2 \%$ にあたる 2,449 名 が受診した. 空腹時採血が得られなかった158名および 追跡開始日以前に死亡した 2 名を除いた 2,289 名を今 回の分析対象とした。追跡期間は1978年11月より 1989 年10月屯での11年間とし，この間の死亡について診療 記録，死亡診断書および剖検記録により原死因を決定 した. FBSは，検診時に一晚の絶食後に静脈血採血を 抢こない，グルコース酸化酵素法により測定した。 $\mathrm{FBS}$ (単位 $\mathrm{mg} / \mathrm{d} l$ ) が87末満 ( I 群 1,056 名), 87 以上 110 末満(II 群1,066名)，110以上 140 末満(III群114名)， 
140 以上(IV群53名)で 4 群に層別し, その 4 群間で性・ 年齢を補正した死因別死亡頻度を比較した。 また, Cox の比例ハザードモデルを用いて他の心血管系疾患の危 険因子を含めて FBS が心血管系疾患死亡に与兄る影

\section{響を検討した。}

結果：追跡期間中の総死亡は男性184例, 女性166例, 計350例で，そのうちの $86.3 \%$ に剖検を行なった。男女 の主要死因の内訳は, 悪性新生物が112例, 脳卒中が61 例 ( 5 ち脳梗塞が39例), 心疾患が44例 ( 5 ち虚血性心 疾患が30例) であった。FB 4 群間の比較では, 第IV 群は第 I, II 群に比べて総死亡, 心血管系疾患死亡, 脳卒中死亡, 脳梗塞死亡の危険因子となったが, 虚血 性心疾患死亡の危険因子とならなかった。多变量解析 でもFBS は他の因子とともに総死亡, 脳卒中死亡, 脳 梗塞死亡の危険因子となった。最近の集団でも糖尿病 域の FBS は虚血性心疾患よりも脳梗塞の危険因子と して重要であった。

\section{1. 老年期痴呆の危険要因の分析疫学的研究} 北海道大公衆衛生学

$\begin{array}{rrr}\text { 近藤喜代太郎, 新野 峰久 } \\ \text { 札幌市愛全病院 } & \text { 松島 達明 }\end{array}$

目的：アルッハイマー病 $(\mathrm{AD})$ と, 血管性痴呆の危 険要因をケースコントロール法で調べ，それぞれに固 有の要因と, 非特異的に痴呆化を促進する要因に分け て評価する。

材料と方法：代理回答の有効性. ともに正常な 67 組 の高齢夫婦で, VD 用調査票を用い, 本人と配偶者のこ とを別々に聞き，同一事項の一致性をカッパ統計量で 調べた。

AD. 北大・同関連病院の 34 例， 1 例に対して 2 名の 同性・同齢 (+ +5 歳), 同地方の住民に面接 ( $\mathrm{AD}$ で は配偶者)，135項目を聞取り調査した。

$\mathrm{VD}$ (多発梗塞とビンスワンカー病), 愛全病院の 20 例, 対照群, 面接法は $\mathrm{AD}$ と同じ, ペット・家畜, 職 業性暴露歴を除いた 96 項目を調査した。

結果：代理回答の一致性. 90項目中 88 で有意に一致 し，71が $80 \%$ 以上，29が $90 \%$ 以上一致。

AD. 頭部外傷, 歯牙喪失, 習慣性便秘, 40 歳 50 歳 の無趣味・社会参加の不活発, 低学歴と相関.

VD. 高血圧, 脳卒中, 習慣性便秘，無趣味・社会参 加の不活発，20３0歳の運動不足と相関.

考察： $\mathrm{AD}$ は60例，VDは120例を目標としている が, 現段階でも, 各疾患に固有の要因の他, 器質性病
変の相異を越えた共通の要因があるように思われる。 とくに, VDの場合, 脳病変の起きていない時点で, 精 神的不活発があることが注目される。ライフスタイル の中の痴呆化要因と，それが複合化したときの効果を 計量化して予防に活用したい。

\section{2. 精神老化のリスク・ファクターの検討(第 2 報)} 中高年齢に達した双生児905組の追跡健康調查

近畿大公衆衛生学早川 和生

精神的老化現象に関しては, 遺伝要因と環境要因の 双方の要因が関与していることが考えられる．精神老 化に関する要因を環境面から検討する場合，遺伝素因 が一定にコントロールされた一卵性双生児は有用な研 究対象となる，当教室では，かねてより50歳以上の中 高年双生児について総合的な健康調查を実施している が, 今回, WAIS 成人知能テストの成績と生活環境要 因との関連を検討した。

対象は, 当教室の健康調查に協力を得ている中高年 双生児 905 組のうち，総合的な検診を受診した 110 組で ある．まず，素因の等しい一卵性双生児について別離 年齢別に級内相関係数を比較した。別離年齢 $0 \sim 5$ 歳 では数唱問題, 符号問題とも級内相関が 0.1 以下と低い 数值を示したのに対し，別離年齢20歳以上では級内相 関が 0.8 程度まで上昇した.養育環境の異同の影響がぺ ア内の得点差に関与したことが示唆された。

そこで, 個々の生活環境要因のうち, 職業の軽重, 飲酒量, 契煙量の 3 項目について，ペア内で大きな差 異がみられた一卵性ペアを選んで WAIS 平均得点を 比較した。知的老化に鋭敏な指標とされている符号得 点でみると, 重労働群44.6点に対し軽労働群 48.4 点, 飲酒群53.7点に対し非飲酒群 49.9 点, 智煙群 46.8 点に 対し非喫煙群 49.7 点であった．符号問題の他にも数唱 問題, 積木問題に抢いて同様の差異がみられた。符号, 数唱, 積木の各項目とも年齢が高くなるにつれて平均 得点が低下したことから，知的老化にこれら生活要因 の関与が考えられた。

273. アルツハイマー型老年痴呆のライフスタイル に関する患者・対照研究

国立公衆衛生院

金森 雅夫 都多摩老人医療センター

$$
\begin{array}{rr}
\text { 一瀬 邦弘, 店橋 光枝 } \\
\text { 内山 真, 田中 邦明 }
\end{array}
$$

都老人総合研究所 
七田 恵子, 巻田 らさ, 籏野 脩一 北海道大公衆衛生学近藤喜代太郎

目的：老年痴呆患者の過去のライフスタイルについ て調べ, 健常対照群のそれと比較し, 痴呆患者のライ フスタイルの特徵，危険因子を探索することを目的と する.

対象之方法：多摩老人医療センター精神科外来を訪 れる老年痴呆患者33名を対象とする. 対照群は, 各ヶー スごとに性，年齢を一致させた近隣対照とし，1ケー スに 1 例の割合で無作為抽出した東村山市在住老人健 康診断受診者を対照群 I, 同様に集会参加老人を対照 群IIとしてそれぞれ選定した，対照者は痴呆症状およ び循環器疾患を含まないいわゆる健常者である，調査 はケースについてはその事情を最も知っている家族 に，対照者は本人に面接聴取した，質問項目は，既往 歴, 日常生活での評価(運動, 睡眠, 朝食, 間食, 酒, タバコの生活習慣), 入れ歯, 趣味, 食事内容である. 本研究の特徵は, (1)ケースについては診断が統一され ていること，面接は看護相談の専門員が行い情報が正 確である，(2)質問方法，内容はその妥当性が確認され ている近藤の質問紙によっており, 将来のメタ分析が 可能である, (3)ブレスローらの 7 つ生活習慣との関 連比較が可能であることである.

結果：オッズ比は，既往歴のなかで低血圧1.93，60 歳以降の頭の打撲 $2.40,40$ 歳以降「あまり運動をして いない」3.15などの運動歴, 特定の長く続けた「趣味 がない」 4.85 , 現在歯がない 1.58 , 総入歯 1.46 , 成年 期に「よく歯医者に通った」1.26であった。オッズ比 が対照群 I, II とも高いのは, 運動習慣, 趣味, 短気 で,一方が高いのは, 朝食, 睡眠, 寝つき, 60歳以降 の頭の打撲であった。生活習慣 7 つの項目の総和では 差が認められなかった. Stepwise 法による重回㷌分析 では, 休日の運動, 頭の打撲, 趣味が最初に選択され た。

\section{4. 在宅高踣者における活動的平均余命}

帝京大公衆衛生学

$\begin{array}{lll}\text { 甲斐 一郎, 小林 廉毅 } \\ \text { 東京大成人保健学 } & \text { 大井 玄 } \\ \text { 佐久市健康管理センター } & \text { 木内松代子 }\end{array}$

はじめに：従来，地域の集団の健康指標としては， 平均余命など, 死亡にもとづく指標が用いられていた。 しかし，先進諸国に打いては，人口の高齢化と医療技 術の進歩にともない，死亡にもとづく健康指標のみで
は十分でないことが明らかになってきた、今回，我々 は，地域の在宅高齢者を対象とする追跡調査をおこな い, $\mathrm{ADL}$ にもとづく活動的平均余命 (平均して, あと 何年 ADL 良好な状態で生活できるか) を算出したの で報告する。

対象と方法：1988年 7 月に長野県佐久市において第 1 回調査をおこなった。調査は, この時点で満60歳以 上の全員 $(13,529 人)$ を対象とし, 自記式アンケート によりおこなわれた。調査票を回収できたのは 13,118 名（97\%）であったが，らち転出，長期不在，死亡, 拒否などで白紙のものを除くと，12,903人（95\%）か ら有効回答がえられた。調査珍目は, $\mathrm{ADL}$ ( 6 項目), instrumental ADL (古谷野ら，5 項目), 仕事の有無, 家族構成，学歴などであった。年齢および性別は住民 台帳により確認した。ささらに，1989年 7 月および1990 年 7 月に同様の調査票で追跡調査をおこない, Katz （1983）の提唱する活動的平均余命を算出した。二年間 の観察に指数関数の生存曲線をあてはめ, 60歳以上 5 歳ごとの年秢階層別に, 活動的平均余命および死亡に もとづく通常の平均余命を計算した。なお，90歳以上 は例数が少ないため一括した。

結果：1988年の第 1 回の調査時点で ADL 6 項目の すべてが良好だった者 10,441 人について，活動的平均 余命を算出したところ，65～69歳で11.6年となった. この数值は, Katzの米国に拈ける研究の結果とよく似 かよっていた.一方, これら ADL 良好者について, 平 均余命を計算したところ, 65〜69歳で22.5年であった. また, 90 歳以上の年齢階層を除くすべての年齢階層で, 平均余命に占める活動的平均余命の割合は加齢ととも に低下しており，これす Katzの観察と一致した。

275. 老人性白内障の発症関連因子について（予報） 東京女子医大衛生公衆衛生 加藤 信世 金沢医大眼科

佐々木一之

目的：多施設による患者・対照研究を行ない，老人 性白内障の発症因子の検討を行なった。

方法：患者群は演者らとその共同研究者が所属する 医療施設の眼科に通院または入院中の老人性白内障患 者で, 白内障疫学研究班診断基準の進行程度, II, III, 执よび老人性白内障として手術を受けた無水晶体症例 とした. 対照群は前記の医療施設の受療者で, 診断基 準で正常または初期老人性変化のみを有する者とし た. 両群とも糖尿病患者あるいは白内障を誘発すると 考えられる職業への従事者は対象から除いた，両群に 
ついて性, 年路（土3 歳）によるマッチングを行い, 213組の患者・対照群を対象とした。 マッチングにあ たっては, 可能な限り同じ医療施設での患者と対照と をマッチングさせた。職業でのマッチングは行わな かったが，両群での職業別分布のカイ二乗検定では男 女それぞれ $\mathrm{P}=0.45, \mathrm{P}=0.74$ とほとんど差はみられ なかった。両群に本研究班作成の問診票にて面接調査 を行なった。

結果：体型因子, 戸外での生活時間, 15の食品捸取 状況, 揳煙, 飲酒, 便通, 高血圧等 8 疾患の既往歴, 薬剂服用, 残存歯数, 妊娠・出産, 閉経等につき検討 した，男性で現在の長い戸外生活時間，女性で少ない 残存雨数がそれぞれオッズ比 $4.53,2.03(\mathrm{p}<0.05)$ で あった。

結論：今回調査した因子の中で, 男性での長い戸外 生活時間, 女性での少ない残存雪数が白内障発現と有 意な関連性を示した。紫外線と老人性白内障との関係 については報告も多いが，残存歯数は従来指摘のな かった関与項目である. 患者・対照研究は後乃向き調 査であるため危険因子曝露と発症との時間的関係につ いては明らかではないが，この種の検討は本疾患の危 険因子解明には欠くことのできないむのであり，有用 な情報になり得ると考える。

\section{6. 老年者における温浴療法の効果}

阪和泉北病院内科

\section{佐伯 集一，橋爪喜代子}

美濃 良夫, 大西 利夫

目的：温泉療法は脳血管障害後の麻瘏患者や慢性関 節リウマチ患者の治療に用いられ, また糖尿病, 高血 圧症などにも応用されてきた。当院では温泉療法で行 われてきた入湯の方法をとり入れ，クアミッテルハウ ス的な施設をつくり，淡水の温浴療法として行ってい る.今回我々は 1 回入湯の血圧, 脈拍にする影響と長 期温浴療法（約 3 力月）の身体的, 精神的症状の改善 効果, 血圧, 血液検査などへの影響につき検討した.

万法：対象患者は当院に入院中の脳梗塞後遺症, 脳 動脈硬化症, 骨粗鬆症, 変形性関節症, 大腿骨頸部骨 折手術後, 高血圧症, 糖尿病などの患者約50名（平均 年龄約73歳) で, 入湯は, 打たせ湯, 寝湯, 坐湯, 圧 注湯, 気泡湯, 歩行湯などの 3 分毎の組合せで, 1 日 1 回20〜30分, 週 $3 \sim 5$ 回行った. 拈湯の温度は約 $40^{\circ} \mathrm{C}$ に設定した，治療開始前と 1 力月， 3 力月後に問診, 血圧, 体重測定, 血液検査, 心電図, 呼吸機能検査,
CMI 健康調査表などを行った。

結果 : < 1 回浴について >血圧は入浴中より出浴後 にかけて低下傾向がみられた。脈拍は入浴中より出浴 後にかけて増加を認めたが不整脈の誘発などはなく， 安全に行いえた。（長期効果について>症状について は痛み，しびれ，冷感などの改善例が多かった。血液 検査では 3 力月後で HDL-cholesterol の増加 $(39 \rightarrow 46$ $\mathrm{mg} / \mathrm{d} l), \mathrm{HbA} 1$ の减少 $(8.0 \rightarrow 7.6 \mathrm{mg} / \mathrm{d} l)$ が見られた が有意の変化ではなく, その他末梢血液像, アルブミ ン, 電解質, 肝機能なども有意の変化は認められなかっ た．血圧は下降傾向が見られた（前：145/74mmHg $\rightarrow$ 3 カ月後：136/70mmHg). CMI 健康調査表では神経 症判別図の領域III, IVからIII, II或はII, I へと好転 しており, 易怒性, 強迫観念, 自殺傾向などの項目の 消失例も認められた。この間事故は 1 例も無かった。

結論：温浴療法は老人の慢性疾患に対する補助療法 として安全に行われ身体的にも精神的にも有用である と考えられた。

277. 老年者糖尿病における運動療法の検討一急性 効果の経時的変化と長期トレーニング効果一

都多摩老人医療センター内分泌科

中野 忠澄, 山田 景子

若尾 理恵, 宮川 高一

同 循環器科

同リ八科

井上 剛輔

木村 博光, 今泉 寛

藤田 博暁, 栗原 美智

目的：老年者糖尿病に拈ける運動療法の報告は少な い.そこで, 運動が代謝におよぼす急性効果および長 期トレーニング効果を検討し，老年者糖尿病における 運動の有用性を評価した。

万法：対象は，心電図ダブルマスターテストが陰性 で, トレッドミル歩行を安全に実施しらる60歳以上の 糖尿病患者 15 例（男 9 例，女 6 例，平均年齢70歳）で ある，運動は，予め多段階トレッドミル運動負荷試験 によって得られた予測最大酸素消費量の $60 \%$ 前後の負 荷に相当するトレッドミル歩行を, 食後 3 時間後に, 5 分の休みをはさんで計20分間行い, 運動前, 終了時 および終了15分後の血中の糖・脂質・ホルモンを測定 し, 運動の急性効果を検討した. 15例中 5 例は上記運 動を週に $2 \sim 4$ 回， 1 年間以上継続し， 3 力月毎に急 性効果の経時的変化につき検討し, さらに, 長期トレー ニングが, 体重, 血糖のコントロール状態, 血清脂質 など代謝に执よぼす効果につき検討した。 
結果：(1）運動前に比し, 運動後には, 血糖及び IRI は低下し, FFA, 乳酸, ケトン体およびカテュールア ミン等諸ホルモンの増加を認めたが，正常範囲内での 変動であった。長期トレーニングを実施し得た糖尿病 例 5 例において, トレーニング開始 $3 ， 6 ， 9 ， 12$ 力 月後においてもこれら指標の運動に伴う変動のパター ンに著しい変化はみられなかった。な拉，血圧・心拍 の異常な変動や運動を中止すべき症候はみられず，心 電図上も虚血性 ST-T变化や不整脈は認められな かった。（2） 1 年以上の長期トレーニングを継続した 5 例では, トレーニングを行わなかった 5 例に比し，

Body Mass Index 拉よびへモグロビン A1c 值は, 減 少を示したが，空腹時血糖値，耐糖能及び血清脂質は 一定の傾向を示さなかった。なお，新たな合併症の発 生や進展は認められなかった。

結論：老年者糖尿病に扮いても，適応のある症例を 選んで行えば, 運動療法は, 安全かつ有用であること が示唆された。

\section{8. 横隔膜誘発電位の加齢变化}

名古屋市総合リハビリテーションセンター 神経内科紙本薫, 日比野敬明

蒲沢 秀洋, 松原 充隆

目的：重要な呼吸筋である横隔膜に対する加齢の影 響を把握するために，各年代別の横隔膜誘発電位を解 析することにより検討を行った。

対象: 健康成人 80 例（男性 48 例, 女性 32 例, 平均年 歯51歳）を対象とした。その内訳は20歳代12例，30歳 代12例，40歳代13例，50歳代16例，60歳代11例，70歳 代12例，80歳代 4 例である.

方法：横隔膜誘発電位の記録は右頸部胸鎖乳突筋後 方より経皮的に電気刺激を与兄，右第 7 肋間の表面電 極より導出した。この誘発電位の測定を刺激頻度 0.5 , $1,3,5 \mathrm{~Hz}$ で各 10 回の連続誘発電位の記録も行った. 誘発電位の解析は横隔膜伝導時間, 振幅により行い, 連続誘発電位は各刺激頻度に拈ける振幅の平均と 0.5 $\mathrm{Hz}$ 刺激での平均振幅を 1 とした時の $1,3,5 \mathrm{~Hz}$ 刺激で の平均振幅比を算出し検討した. 同時に肺機能, 正中 運動神経伝導速度も測定した。

結果 : 年齢と横隔膜伝導時間との間には正の相関が みられ, 年齢と振幅, 肺機能, 正中運動神経伝導速度, $1,3,5 \mathrm{~Hz}$ の平均振幅比との間には負の相関がみられ た。 また横隔膜伝導時間は40歳代以降有意な延長がみ られ, 振幅, 肺機能, 正中運動神経伝導速度, 1, 3,
$5 \mathrm{~Hz}$ の平均振幅比は60歳代以降有意な低下がみられ た。さらに横隔膜伝導時間と肺機能および正中運動神 経伝導速度との間には負の相関がみられたが, 振幅と 肺機能の間には相関はみられなかった。

結論：加齢とともに横隔膜伝導時間の有意な延長や 振幅の低下など横隔膜機能の低下が示唆され, 特に60 歳代以降で横隔膜機能の低下が明らかとなり, 老年者 の呼吸機能や合併症としての肺感染症発症の面からも 注意すべき点と考えられた。横隔膜誘発電位は加龄に 伴う横隔膜機能低下を検出することが可能であり, 老 年者の横隔膜機能を把握する上で有用な検査法と考兄 られた。

\section{9. リハビリテーション専門病院における脳卒中} 後遺症患者の検討
山口大神経内科
野垣宏, 福迫 俊弘, 佐々部富士男
山本 清, 高瀬 良孝, 森松 光紀
山ロリハビリテーション病院 福岡 善平

目的：高齢化社会が叫ばれている現在, 脳卒中後遺 症のリハビリテーションは医学的のみならず社会的に も注目を集めている分野である。そこでわれわれは， リハビリテーション専門病院（以下，リ八専門病院と 略す)における脳卒中入院患者について検討を加光た。

方法：リ八専門病院に入院中あるいはすでに退院し た脳卒中患者 312 名(男200名, 女112名, 平均年齢65歳) について, 発症から入院までの日数, 入院期間, 紹介 元, 退院先, 入院時 Barthel index (以下, B.I. と略す), 入院時自立度 (二木の分類による), 退院時 B.I., 退院 時自立度について調べた。

結果：発症からリ八専門病院入院までの平均日数は 433日, 退院者225名の平均入院日数は244日であった。 紹介元では自宅から 90 名, 総合病院から152名, 老人病 院から13名, 個人病院から51名であった。退院先では 自宅 142 名, 総合病院 18 名, 老人病院 17 名, 老人保健施 設14名, 特別養護老人ホーム10名, 死亡 9 名であった。 入院時 B.I. は平均 59 点, 入院時自立度は屋外歩行 69 名, 屋内歩行54名, ベッド上生活106名, 全介助83名で あり, 退院時 B.I. は平均76点, 退院時自立度は屋外歩 行102名, 屋内歩行43名, ベッド上生活39名, 全介助 31 名であった。退院先別の検討では, 自宅退院群は他の 群に比べ入院時 B.I., 退院時 B.I. とも有意に高かった $(\mathrm{p}<0.01)$. また死亡群全員, 入院時全介助であった。 退院者 225 名の入院期間の検討では, 入院時 B.I. が高 
いほど入院期間が有意に短く $(p<0.01) ， 2$ 年以上入 院していた群はそれ以下の群に比べ退院時 B.I. が有 意に低かった $(\mathrm{p}<0.01)$.

老年医学的意義 : 高齢者の長期入院が社会的問題と してとりあげられ，自宅退院の促進，福祉施設の充実 が重要課題となっているわが国においては，高齢入院 患者の多くを占める脳卒中後遺症の現状の一端を知る らえで今回の報告は意義あるものと考えられた.

280. 高齢者のための行動評価表の作成 (1) 一作成 過程と項目の決定一

都老人総合研究所 - 心理研究室 成田 健一, 下仲 順子, 中里 克治 都老人総合研究所・プロジェクト研究部 本城由美子

本研究は高齢者の Quality of Life の指標開発の一 環として, 特別養護老人ホームなどの老人施設入居者 用の行動評価表を作成することを目的としている．特 養などの施設に住む老人は，従来から行われてきたよ らに，質問紙法によりQOLを評価できない場合が少 なくないため, 老人たちの日頃の生活を熟知している 介護職員により老人の日常生活の質の客観的な評価が 可能な行動評価表を試作した。本評価表は Stockton Geriatric Rating Scale（SGRS）をはじめ，10種類の 行動評価表を参考にして下位尺度を設け項目を作成 し，数度にわたる項目の削除，追加，下位尺度間の項 目の入れ換えを行い 5 下位尺度，66項目を選択した。 今回検討した下位尺度と項目数は, ADL 12項目, 活動 性12項目, 痴呆行動 9 項目, 対人行動14項目, 問題行 動 16 項目，その他 3 項目である。評定段階は 4 段階と L, 総得点, 下位尺度得点共に高得点汪ど能力が高く, 障害されていないことを示している．調查の対象は痴 呆性老人用特養 1 を含む 4 つの特養にすむ男 89 名（平 均 77.2 歳), 女191名 (平均 81.5 歳), 計280名の老人で ある. 平均在所年数は 4.5 年であった。

項目分析の結果, 項目一全体相関が低い項目や, 内 容の類似した項目との相関が高い項目, 回答の分布が 偏っている項目を削除した。 また，質問項目の内容や ワーディングの検討をも行った。「その他」の項目に関 しては，相関の高い適切な下位尺度に移動した。その 結果, ADL 10項目, 活動性 9 項目, 痴呆症状 9 項目, 対人行動12項目, 問題行動11項目, 計51項目となった。 51 項目全体での内的整合性を示すCronbach の $\alpha$ 係 数は.941, 各下位尺度の $\alpha$ 係数は, $\mathrm{ADL}=\cdot 885$, 活
動性；.800, 痴呆行動 $=.800$, 対人行動 $=.894$, 問題 行動=.781であり, 総得点およびすべての下位尺度で 高い数值が得られ，十分な信頼性があることが示され た。

281. 高齢者のための行動評価表の作成 ( 2 ) 一妥当 性の検討一

都老人総合研究所・心理研究室

中里 克治, 下仲 順子, 成田 健一 都老人総合研究所・プロジェクト研究部 本城由美子

（1）で作成された51項目 5 下位尺度からなる行動評 価表の妥当性を，ヶース記録等から得られた变数およ び，心理スケールや測定により直接本人から得られた 变数などの外部変数と下位尺度との関係から検討し た。比較した変数は，主観的健康感や障害度，人格変 数, 対人関係, 認知能力などの心理スケール 8 種類と 移動能力, 握力の測定結果など34変数である.

各下位尺度と外部变数との関係については, ADL は トイレの声かけ (-.799), 移動手段 (.637), 活動範 囲(.618), 長谷川スケール(.543), 寝たきり度 $(-.433)$ とかなり高い相関が得られたが，手足の麻痺箇所数と の相関 (一.336)は低かった。活動性は活動範囲(.561), 視力 (.436), 寝たきり度 $(-.434)$ と相関が高かった。 痴呆行動は長谷川スケール (.707), 痴呆症状の数 (.516) と相関が高かった。対人行動は長谷川スケール (.547)，活動範囲(.414)，Affect Balance の肯定感情 (.341), 視力 (.329), 聴力 (.307) と様々な要因と関 係していたが，面会頻度（.015）とは相関が認められ なかった。問題行動は問題行動数 $(-.665)$ と相関が 高かった。 5 下位尺度を総合した総得点は長谷川ス ケール (.685), 活動範囲 (.558) と相関が認められた。 また，年齢，性別，入所年数，教育の諸变数は，総得 点拉よびいずれの下位尺度とも相関は有意ではなく， 本評価表が老人の基本属性を考慮せずに使えることが 示唆された。

これらの結果から，ADL，活動性，疾呆行動に関し てはそれぞれ外的な指標との関係が明確であり，妥当 性が示された．外人行動と問題行動については，今回 の調查では対応する外的な指標が少なく今後さらに検 討する予定である。

282. 大学病院リハビリテーション科診療の動向 一特に高齢者についてー 
東海大リハビリテーション学

$$
\begin{aligned}
& \text { 木戸 保秀, 豊倉 穣, 尾上久一郎 } \\
& \text { 古川 俊明, 本田 哲三, 石田 暉 } \\
& \text { 村上 恵一 }
\end{aligned}
$$

目的：リハビリテーション医療の対象となる疾患・ 障害は多岐に渡る。そのニーズは年々高まる一方であ り, 高齢者の占める割合も少なくない.今回我々は, 当科新患者受診の動向を調査し，特に高齢者に多い大 腿骨頸部骨折症例のリハビリ医療実践の経緯について 検討を加觉た。

対象・方法：過去 9 年間の新受診患者の内, 1981年, 1985年, 1989年度 (以下'81, '85, '89)をサンプリング 対象（合計約 3,800 例）とした.リハビリ科受診記録, カルテをもとに疾患, 年㱓, 入院・外来の別を調査し, 対象疾患内訳や経年変化を, さらに大腿骨頸部骨折患 者に対しては，手術からリハビリ依頼までの日数，在 院期間，既存障害の有無なども調べ，それらの経年的 変遷を検討した。

結果・考察：年度別新患者総数は, '81：997例, '85： 1,204 例, '89:1,594例と年々増加している. 入院・外 来の比は約 $7 ： 3$ と前者の割合が多く, 年度毎の変化 は少なかった，年㱓分布は，いずれの年度も20歳およ び50歳前後にピークをもつ 2 峰性を呈した。新患者総 数に占める65歳以上の高齢者の割合は, '81：18.9\%, '85：19.5\%，'89：17.9\%とほぼ一定の傾向を示した. しかし, '89では95歳以上の超高齢者に対するリハビリ 依頼も見られている。65歳で分けた高齢者と若年者の 疾患分布を見ると, 前者では脳血管障害, 悪性腫瘍, 大腿骨頸部骨折，後者では，外傷の割合が多い。これ は各年度ともほぼ一定の傾向が続いている。大腿骨頸 部骨折症例の年度別平均年龄は, '81:61.5歳 (15例), '85：62.4歳 (19例), '89：66.9歳 (45例), さらに80藏 以上の占める割合も，同様に $13 \% ， 26 \% ， 56 \%$ と年々 高齢化が進んでいる。これに伴い, 高血圧, 糖疗病, 脳血管障害などの既存障害をもつ患者に対するリハビ リの機会が増えている. 一方, 手術より当科依頼まで の日数は年々短縮し, '89では約30\%に術前依頼が出さ れ，術後〜自宅退院までの期間も，62日，55日，40日 と早期リハ, 早期退院の傾向が明らかであった。

\section{3. 老人保健施設における日常生活動作の調査}

国立仙台病院附属リハビリテーション学院 秋山 純和, 渡辺 好孝

目的：1988年 1 月より実施されている老人保健施設
は医療と福祉の機能を持った新しい制度の施設であ り，その目的は老人の自立機能の回復となっている. このため, 日常生活動作（ADL）に対する援助が重要 な課題となっているが利用者の実態は必ずしも明確で はない.この点について, 我々は, 今後のリハビリテー ション, 理学療法の参考とするため, 東北 3 県 4 施設 における利用者の ADLを調査した。

方法：老人保健施設における ADLの調査はLehmann の評価を参考とした。観察法により 5 点順序尺 度で評価し，採点した，点数は概ね，1点：全介助， 2 点：一部介助, 3 点：補助具などの使用で自立, 4 点：自立，ただし正常動作ではない，5点：正常動作 であり,とした。

ADL の項目は食事動作, 更衣動作, 排尿動作, 排便 動作，移乗動作，歩行動作の 6 項目とした。

対象施設は秋田県 2 箇所, 青森県 1 箇所, 宮域県 1 箇所の合計 4 施設であり，対象数は302名であったが, このうち 8 名を欠損值とした. 性別では男性100名, 女 性194名であった。年齢は60歳台 17 名，70歳台 138 名， 80歳台129名, 90歳台10名であった。

結果：年齢別では60歳台が70歳台, 80歳台に較べ最 も低く,70歳台, 80歳台と高齢になる程, ADLの点数 が高くなった。個々の ADLでは食事動作で最も点数 が高く，歩行動作では最も低い点数にあった。

考察：高秢になる程, ADL が自立している結果を得 たが，60歳台では ADL の自立しているものが少なく， 家庭では重度の介助を必要とすると考兄られた。一方, 80歳台ではADL といらよりは，家庭における介護者 がいない，家族との関係が良好でないという医学的で ない理由のものもみられた、今後の高齢社会に打ける 老人保健施設においては, ADL 訓練とともに家族との 支援，調整がより一層，重要な課題であると考学られ た。

\section{4. 老年者心筋梗塞患者の退院後の活動状況}

都老人医療センターリハビリテーション科 藤沢 明子, 望月 直哉 林 泰史, 上田 慶二

同 理学療法科

小沼 正臣, 山本 信行, 久保 晃 千野根勝行，古名 丈人，久寿米木和繁

同 循環器科大川真一郎

目的：急性心筋梗塞 (AMI) リハビリテーション(リ) 八)を施行した老年患者の退院後の生活状況を調査し, 
老年者の慢性期のリハの必要性について検討した。

対象と方法：昭和 60 年 1 月より平成 2 年 3 月までの 間に当センターの AMI リハプログラムを施行, 歩行 退院し, 生存が確認されている98名を対象に郵送によ るアンケート調査を実施した(回収率 $81.6 \%$ ). 対象者 の調査時平均年齢は, $76.0 \pm 8.1$ 歳, 退院時平均運動耐 容能は, $3.8 \pm 1.5 \mathrm{Mets}$ であった。

結果および考察：NYHA 分類に準じた自覚症状の 調査では，I，II群で 8 割を占めた。退院後の生況状 況は“寝ている”“身の回りだけ”“家庭内役割あり” “地域活動”の中から選択させたが，全体で38\%が積極 的に地域活動を行なっており，男性の方が有意に女性 より活動的であった。自覚症状や生活状況は，退院時 運動耐容能と関係があった。 又 $2 / 3$ 以上が脈拍測定, 血 圧測定, 体重測定, 禁煙等の健康管理を励行しており, 約 6 割が日常活動を自ら制限している一方, 運動の必 要性を感じているものが 7 割, 何らかの運動を施行し ているものが 6 割, 身体に合った運動の指導を希望し ているものが 6 割以上あった. 日常労作では, 殆ど全 例が浴漕入浴をし，約半数が階段昇降を行ない，荷物 を持っての階段昇降も5 例 $(6.7 \%)$ いた. 入浴以上の 労作を行なっていない群31例の退院時運動耐容能 $3.3 \pm 1.3 \mathrm{Mets}$ に対し, 階段昇降等の入浴以上の労作

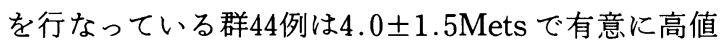
であったが，いずれも一般に報告されている入浴や階 段昇降に要する Metsよりも低值であり老年者におけ る日常労作に対応する Metsについての再検討が必要 と思われた。

結語：老年者における慢性期の系統的，包括的なり 八の必要性が示唆された。

285. 障害老人の入院リハビリテーションー維持的 リハビリテーションについてー

浴風会病院内科 八田 美鳥, 大友 英一

目的：入院リハビリテーション(リハビリ) の目指 すものは家庭復帰にあると思われるが，重度障害また は介護環境の理由により, 長期入院の後, 特別養護老 人ホーム (特養) へ入所する障害老人は少なくない。 これら患者について高齢者の維持的リハビリの必要性 を ADL 能力を中心に検討した。

対象：1989年 6 月現在, 当院一般病棟に入院中の特 養申請患者 46 例中, 1 年後の 1990 年 5 月までに死亡し た 7 例を除く 39 例(男 6 例，女 33 例，平均年齢 81.4 歳) を対象とした。
結果および考察：1）疾患；重複障害が多いが, 主た る疾患では脳血管障害17例，パーキンンニズム 3 例, 他の神経疾患 4 例， 大腿骨頸部骨折 6 例，他の骨関節 疾患 3 例，その他 6 例であった. 2) 合併症；高血圧症 が14例と最も多く,ついで心疾患 9 例, 糖尿病 4 例で, 痴呆や抑麾症状もそれぞれ15例，6例に見られた，3） 経過；すでに退院・入所例ではその時点までの，入院 中の例では1990年 5 月までの経過で検討し，全体では 能力改善18\%, 維持69\%で悪化はわずかに13\%に見ら れたのみであった。悪化例では内科疾患の重篤化の他

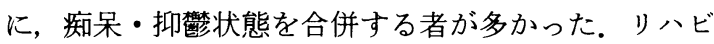
リ実施の有無により 3 群に分けての検討では，各群間 の背景因子が異なるため単純比較は出来ないが，長期 PT 実旋群で能力改善が $24 \%$, 悪化が10\%に認められ, 他の 2 群に比し良好な経過を示した。

結語：高齢者のリハビリの目標は，廃用性障害を防 止し日常生活の基本動作を維持することであろう。し かしそのゴールにも達することが出来ず，むしろ加齢 と共に能力低下寸る事が確実である高齢者に対して も，リハビリは有用であると考える。

\section{6. 秋田県における65歳以上老人の介護状況につ} いて

秋田県立脳血管研究センター疫学研究部

鈴木 一夫

目的：老年人口が増加するに連れ, 在宅の痴呆老人, 寝たきり老人の介護対策が緊急課題となってきてい る。これらの状況にある要介護老人の実態を明らかに 乙問題の大きさを計測し，対策を樹立する基礎的分析 を行なった。

方法：1989年 7 月に秋田県に在住する65歳以上老人 18万人を対象に悉皆調査を行なった。調査が対策に結 びつくために全対象者に ID をつけ，データベース化 した。

結果：在宅の回答者は 155,845 人であった.明らかな 記銘力障害や問題行動を持つ老人（痴呆様老人）は $5.7 \%$ でり，そのために家族の介護を要する老人(要 介護痴呆様老人) は 3,712 人 (2.3\%) であった。これ を動き回れる群 ( 1 群), 動きが制限される群 ( 2 群), 寝たきりの群（３群）に分けてみると，それぞれ67\%， 14\%，18\%であった．各々の群の脳卒中既往歴を有す

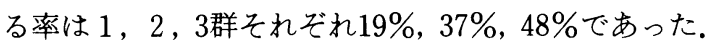
要介護痴呆様老人は年齢が高齢になる泀どその出現率 は増加し，90歳～94歳でピークに達する。これを群別 
にみると，1 群では 85 歳 89 歳, 2 群では 90 歳 $~ 94$ 歳, 3 群では95歳９9歳でその率が最も高くなった。要介 護痴呆様老人は女が59\%をしめた。しかし，その出現 率は男女それぞれ，2.3\%，2.5\%であった。65歳から 79歳にかけての年路では男のそれが女を上回った。こ の年齢の男では要介護疾呆様老人の $44 \% か ゙$ 脳卒中既往 歷を有していた。さらに，この中の $28 \%$ は寝たきりで あった。痴呆様症状を合併しない寝たきり老人は全体 の $1.1 \%$ であった. 以上の結果から様々な障害を合併し た老人群の人数や年齢・性の特徵が明らかとなり，有 効な対策を立てるための基礎資料の役割，さらに個々 の例に介入したときの評価が可能になると思われる.

\section{7. 在宅80歳老人の日常生活動作 (ADL) と長谷川} 式簡易知能評価スコア

$\begin{array}{llr}\text { 国療南京都病院神経内科 } & \text { 宮原 } & \text { 忠夫 } \\ \text { 京都文教短期大家政学部 } & \text { 池田 } & \text { 順子 } \\ \text { 京都大老年科 } & & \\ \quad \text { 浅田 武夫, 村井 淳志, 北 } \\ \text { 京都桂病院内科 } & \text { 辰巳 } & \text { 裕之 }\end{array}$

目的：在宅老人の生活と健康の実態を知るために, 日常生活動作 (ADL) の調査と長谷川式簡易知能評価 スケールによる検查を施行し，それらの相互関係を検 討した。

方法：京都府内の在宅 80 歳老人より，無作為に抽出 した, 男性190名, 女性256名, 計446名に, アンヶート と保健婦などの調査員による訪問調査を行なった。

ADL は, 起立・歩行, 食事, 排泄 (失禁), 入浴, 着替えを，それぞれ 4 段階で評価した。更に, ADL と 関係すると考兄られる聴力と視力を調べた. ADL の総 合評価のために，各項目の 4 段階評価を 0 から 3 点に 配点し，その合計点を算出した。亦た，日常生活での 活動の範囲を調査した。

結果 : 長谷川式知能評価のスコアの平均は 27.5 点で あった．ADLは，歩行は，73\%の人が自立して抢り， $24 \%$ のが半自立で, 介助を要する人は, わずかであっ た。食事，排泄(失禁)，入浴，着替えは 9 割前後の人 が自立していた。

日常生活の活動範囲は，42\%の人がしばしば電車や バスで外出することがあり，46\%の人が自宅近くを出 歩いていた，寝たり起きたり〜寝たきりの人は，3\% 弱であった。

聴力は， $74 \%$ の人が普通に聞こえ，視力は， $77 \%$ の 人が普通に見えると回答していた。
これらの ADL と生活の活動範囲および長谷川式知 能評価のスコアの間には, いずれも強い相関が見られ， 互いに関連の深いことが明らかにされた。

288. 痴呆老人の性行動の ADLに及ぼす影響 小山田記念温泉病院婦人科亀谷謙 同内科出口晃, 川村 耕造 同リハビリテーション科白石 成明 第 2 小山田特別養護老人ホーム

須藤 和代，原田 茂樹

目的：老年の性機能がどの程度に持続し健康状態に 影響するものかを検討する目的で本研究をおこなっ た.

方法：今回は，第 2 小山田特別盖護老人ホーム（痴 呆老人を主として収容する施設）に於て，性行動のあ る人の健康状態や ADL が, 性行動のない人に比べて どのように推移するのかを調查し, 比較検討し, 併せ $\tau$ testosteron, $\beta$-endorphin 值についても検討した.

対象は 100 人の入所者の中で性行動, 性交の認められ た A 群 5 名(男 4 名，女 1 名，年齢70歳 $~ 90$ 歳)，キッ ス, 握手, 会話等のプラトニックな交際と思われるも の B 群 4 名（男 3 名，女 1 名，年齢79 - 87歳）と，そ れらの認められないコントロールC 群14名（男 8 名, 女 6 名, 年齢 $75 \sim 85$ 歳) である. 入所期間は 1 年以上 である。

結果：A，B，C 各群で ADL が入所時と現時点でど のように变化するかを $\mathrm{t}$ 検定にて検討した． $\mathrm{A}$ 群 ; 入 所時 $18.6 \pm 3.0$, 現時点 $15.6 \pm 4.5$, 差 $3.0 \pm 3.4$ で低下 していない.B 群 ; 入所時 $17.3 \pm 3.9$, 現時点 $10.5 \pm$ 7.6, 差6.8土4.5で10\%の危険率で低下している。C 群 ; 入所時 $18.4 \pm 2.3$, 現時点 $11.6 \pm 8.7$, 差 $6.8 \pm 6.9$ で $1 \%$ の危険率で有意に低下している. A 群のみに testosteron と $\beta$-endorphin 值の間に正の相関がみら れた $(\mathrm{r}=0.84, \mathrm{p}<0.1)$.

老年医学的意義：以上の結果より ADL が A 群の 性行動, 性交の認められた人々では余り悪くならない, $\mathrm{B}$ 群のプラトニックの群もついで ADL の低下は少な く, C 群のコントロール群では ADL が有意に低下し ている.

このことは75〜85歳の老齢になっても，性行動のあ るものは ADL が低下しないしまたプラトニックラ ブ即ち会話, 握手, 体にふれるだけ等でも異性との交 渉があると ADL は少ししか悪くならないことが分か る. 
この研究で老齢の健康にSex が大きく関与してい ることが分かる。

\section{9. 褯痽発生要因に関する Case-Control Study} 都老人総合研究所

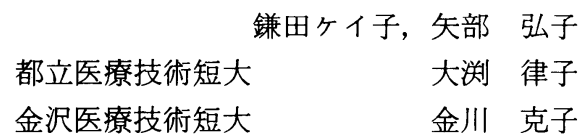

目的：裖瘡予防はいまもって在宅はもとより病院内 においても十分に達成されていない状況にある。した がって裖瘡発生を予防していくことが老人看護の重要 な課題となっている.

そこで，裖瘡発生に直接かかわっていると考えられ る risk-factor を抽出することにより,科学的な褯瘡予 防対策を確立することを目的に調査を実施した。

方法：裤瘡発生早期の老人患者（発生群）と漫返り ができない状態で裖瘔発生のない老人患者（対照群） を約 6 カ月間にわたり10施設で把握し観察した。把握 された発生群61名と対照群63名を比較対照して, $\mathrm{ADL}$, 失禁, 栄養状態等褯瘡発生要因を $\chi^{2}$ 検定により 分析した。

結果: 発生群, 対照群とも年龄は70歳以上の者が $70 \%$ 占め，また疾患も脳神経系が $40 \%$ を占めて最も 多い.

基礎的発生要因といわれる寝返り能力, 意識, 呆け, 麻㿁, 尿失禁については両群に差がみられなかった。

発生要因として有意差のみられたものは，皮膚のず れ (あり …発生群 $35 \%$ ・対照群 $8 \%$ ), 皮覤疾患（あり $\cdots 33 \% \cdot 15 \%$ ), 皮㖸の菲薄（あり $\cdots 66 \% \cdot 44 \%$ ), 疾 患の状態（急性期 $25 \% \cdot 13 \%$ ，末期 $28 \% \cdot 14 \%$ ), 発熱

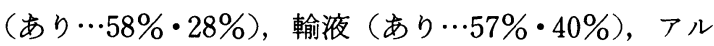
ブミン值 $(2.8$ 以下 $\cdots 39 \% \cdot 18 \%)$, 入浴（なし…51\%・ 33\%) であった.

今回の対象者は, 基礎的な発生要因のらち浸返り, 意識, 呆け, 尿失禁については両群が偶然にコントロー ルされた状態にあり, 褯瘡発生の直接的なひきがねが 皮唐の状態 (ずれ, 菲薄), 全身状態の悪化（発熱·輸 液), 栄養状態の悪化にあることがわかった。ささにケ アとして入浴の有無が大きく作用していた。

290. 高齢者の入浴中の死亡事故について一第 2 報 足利赤十字病院内科 横山 健次, 長嶋 厚樹, 谷 源一
小松本 悟, 奈良 昌治

高齢者の入浴中の死亡事故に対して，十分な関心が 払われていると言い難い，今回昭和 53 年 平成元年の 12 年間に杤木県内で入浴中に死亡して検屍の対象と なった症例953例(男566例，女387例)につき検討した。 これらの例を年代別に比較すると，70歳代で343例と ピークを示し，60歳以上の高齢者は740例と全体の約 $80 \%$ を占めている.この数は同じ 12 年間の 60 歳以上の 高龄者の交通事故死亡者数よりも多い。また各年毎に 死亡者数の变動をみると, 昭和53年には 43 例， 54 年に は35例であったが，昭和63年には140例，平成元年には 117例と増加傾向にある.殊に高齢者の死亡事故の増加 が目立っている，入浴中の死亡事故の死因としては， 若年者ではその大部分が溺死によると思われる。一方 高齢者では，心疾患，脳卒中など何らかの疾患が先行 し死亡すると考兄られる。検屍で推定した死因は，心 蔵死648例, 脳卒中死196例, 溺死等々の他の死亡109例 と心臓死が圧倒的に多かった。ただし，検屍に際し解 剖を行うことは稀であり，春髄穿刺または大槽穿刺を 行い, 髄液が血性であれば脳卒中死として扱いそれ以 外は心臓死とする慣例がある。従って心臓死の中に, 脳梗塞死または脳室穿破を伴わない脳出血死が相当数 含まれているものと思われる。またこれらの死亡例を 月別に検討すると 12 月 170 例, 1 月 130 例と冬期に多く, 7 月 29 例， 8 月 23 例と夏期に少ない。この理由として は, 脱衣する場所と湯温の差が冬期には大きく循環動 態に対し大きな影響を与えることが予想されること， 冬期には長湯になりやすいこと，また湯温が高くなり やすいこと，などが考兄られる，今回入浴中の死亡事 故と季節の関連についてを考慮するにあたり，他県の 統計と比較して検討した。今後高秢化社会が進むにつ れて一層入浴中の死亡事故が増加することが予想され る.入浴に伴う危険について啓蒙し事故を未然に防ぐ 必要がある。

\section{1. 老人ホーム入所者の転倒と関連する要因 昭和大衛生学 新野 直明}

目的：老人の転倒は, 発生頻度が高く,また, 寝た きりの大きな原因の一つといわれる重要な問題であ る. 本研究では, この老人の転倒の誘因を探る目的で, 老人ホーム入所者の転倒の有無と関連する要因につい て検討した.

万法：軽費・養護・特別養護老人ホーム入所者の中 で, 単独立位可能な者(補助具使用の有無は問わない) 
を対象に, 性, 年齢, 握力, 補助具使用の有無, 知的 レベル, ADL, 治療中の疾患, 平衡機能を調べた。次 に, 上記要因調査後 1 力月間の対象者の転倒状況を, 寮母拉上び対象者の報告から調べ，各要因と転倒の関 係を検討した。

結果：対象者は, 男性37名, 女性108名の計145名で, 平均年齢は，それぞれ79.0歳，80.0歳であった。

これらの対象者について，転倒の有無と $5 \%$ で有意 に関連した要因は, 握力 (弱い), 脳血管疾患の有無 (有 り), 整形外科的疾患の有無（有り）の 3 要因であり, 括弧内の場合に転倒が多い傾向が認められた.

次にこれら 3 要因に性と年齢を加えた 5 要因をアイ テム，転倒の有無を外的基準として数量化II類による 分析を実施した。その結果, 要因相互の影響を考慮し ても，握力の弱いこと，脳血管疾患のあることが，転 倒の発生と強く関係するという結果であった。

以上の調査は, 対象者が少なく, また, 疾患の有無 をカルテの病名のみから判断した，1 1 月間といら短 期間の転倒状況しか調べなかったなどという問題点も ある、そのためこの結果から, 転倒の誘因をいうこと はできない，しかし，転倒に関係する生理的変化とし て筋力の低下が大きな意味を持つこと, 各種疾患の存 在が転倒の危険性を高めることなどは，これまでにも 指摘されて打り, 今回の握力と脳血管疾患の有無とい ら要因が, 転倒発生の risk を示寸指標の一つとなる可 能性はあると考えられる。

\section{2. 老人の転倒予防の看護ヶアに関する研究一入} 院老人の転倒発生要因について一

金沢大医療技術短大部看護学科

$$
\text { 金川 克子, 泉 } キ \exists \text { 子 }
$$

目的：老人の転倒に関してさまざまな報告がみら れ，その要因として患者側，環境側から把握されてい る.しかし, 転倒時に患者の意図した行動や看護者に よる転倒のアセスメントを取入れた検討は少ない。本 研究の目的は, 入院中の老人の転倒発生時の特徵, 転 倒に至った行動, 看護者がアセスメントした転倒の原 因を把握することにより，転倒発生の要因を推測する ことである。な沶，転倒の定義は，“身体の足底以外の 部分が床に着いたもの”とした。

対象と方法: 調査対象は, 石川県と近郊の13の中規 模病院（ベッド数100〜 450床）で，1988年10月～1989 年12月までに発生した転倒者と転倒件数である。調査 方法は prospective study であり, 転倒発生時と同一
時間帯に勤務している看護婦に一定様式の項目からな る調査用紙の記入を依頼した。調査項目は, 性, 年齢, 疾病や障害の種類, ADL の程度, 服薬状況, 転倒時間, 場所, 時刻, 転倒時に意図した行動, 看護婦が判断し た転倒の原因と予防方法である。

結果：転倒者は 113 人（転倒件数169件）であり, 男 48 人，女 65 人であった。年齢別では， 70 歳台が $43 \%$ と 最も多く，次いで80歳台の $31 \% ， 60$ 歳台の $20 \%$ の順で あったが，男では70歳台，女では 80 歳台が最も多かっ た。

転倒による損傷は転倒件数169件中, なんらかの損傷 がみられたのは114件であり, 骨折者は17人であった。 転倒者の主な疾患は脳血管障害が 72 人と最も多く,つ いで骨関節疾患, 高血圧, 糖尿病の順であった。 また, 障害では運動障害が最も多く, 次いで痴呆, 視力障害 の順であった。

移動動作レベルでは, 歩行自立が 51 人, 車椅子移動 が 27 人, 歩行介助一監視レベルが 22 人であった。転倒 時の行動の意困はトイレへの往復に関するものが多 かった。看護面からの転倒予防として, 監視, 観察の 必要性, トイレ, はきものの工夫等の提案であった。

\section{3. 老年者の不眠に関する研究 東京医大老年病科 \\ 高崎 優, 羽生 春夫, 馬原 孝彦 佐々木明徳, 勝沼 英宇}

老年期の睡眠障害はその原因として，加齢に伴う体 力の同化機構の低下及び自律神経機能低下による生理 的睡眠障害に加えて, 老年期に増加してくる各種身体 疾患が不眠の背景因子になり得る事が考えられる。そ こで老年者の不眠を支配する要因を探求する目的で 60９6歳の各種慢性疾患患者137例に対して睡眠に関 するフンケート調査を行い，同時に安静時脳波と頭部 $\mathrm{CT}$ 所見，副交感神経機能検査として心電図 R-R 間隔 变動係数及び数種の臨床検查データを加えて多次元的 分析手法により検討を行った。自覚的に不眠を訴えた 不眠群 (101例) について数量化II類を適用した処, 相 関比 $\eta=0.536$ で非不眠群と有意に分離した。 不眠に対 する主な寄与項目は, 起床時気分不調 $32.51 \%$ で最も高 く, 次いで日中の居眠り $17.04 \%$, 高血圧 $13.73 \%$, 食 欲不振 $10.99 \%$ ，心配事あり $9.11 \%$ の順であった。次に 不眠群を, 入眠障害, 熟眠障害, 中途覚醒, 早朝覚醒 の 4 つの型に分けて同様の解析を行った結果では, $\eta=0.29 \sim 0.48 て ゙ 4$ 群は分離した. 寄与項目は, 入眠障 


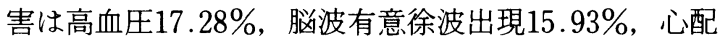
事あり $10.92 \%$ ，日中居眠り $7.03 \% ，$ 他が関与し，熟眠 障害は日中運動なし $28.22 \%$ ，日中身体不調 $20.56 \%$ ， 心配事あり $11.47 \%$ ，中途覚醒は起床時身体不調 $27.39 \%$ ，心配事あり $16.6 \%$, 高血圧, 日中居眠り，CV $\mathrm{R}-\mathrm{R}$ 低値の順で，早朝覚醒は日中身体不調 $22.83 \%$, 脳 波 $\alpha$ 波異常 $21.48 \%$, 肥満, 痴呆の順であった. 1 回以 上中途覚醒した症例は98例で，覚醒原因は夜尿が $45.6 \%$ で最も多く, 次いで原因不明 $18.4 \%$, 外部騒音 $9.6 \%$ ，関節・腰部疼痛 $8.8 \%$ であった。老年者の慢性 不眠の原因は必ずしも全てが脳の退行現象の反映では なく，生活状況や身体的条件之も関連が深く，その要 因として身体的要因，心理的要因，及び加跘による自 律神経機能低下などが複雑に絡み合って不眠の多様性 が構築されているものと考えられる。

\section{4. 老人患者の外来通院における問題}

北里大看護学部, 北里大東病院 ${ }^{1)}$

聖路加看護大学 ${ }^{2}$

竹崎久美子, 溝口 満子, 鳥澤 美世1) 細谷百合子11 石井 享子'2) 小森 元子11 深瀬須加子

目的：漫たきり老人対策等に比し，外来通院可能な 老人患者やその家族が抱光る通院負担に対しては，ま だ注目されていない，しかし通院可能な時期からの支 援こそ, これからの老人医療, 福祉の最重要課題であ ると考える，本研究では，身体的に不自由な老人の通 院実態から，患者及び付添ら家族の持つ負担を明らか にし，今後の支援の方向性を探ることを目的とした。

対象及び方法：平成元年 8 月現在，北里大学東病院 慢性難治性疾患七ンタ一外来に通院している患者のう ち，身体に障害を持ち，近医では管理の困難と思われ る 5 疾患, 118名の患者と付添い者79名に対し，聞きと り調査を行った。 5 疾患の内訳は，パーキンソン病 82 名, リウマチ 22 名, 春髄小脳変性症 10 名, 筋萎縮性側 索硬化症 3 名, 後緥じん帯骨化症 1 名, 患者の年跲は, 60歳代59名，70歳代47名，80歳代12名であった。主な 調査内容は，1）通院状況（頻度・方法・所要時間 - 通 院に伴う楽しみと負担)，2）通院途上で困ったこと, 3）病院内で困ったこと，4）付添い者に対しては付添 5理由及び1) 3)，等である。

結果：疾患の特性上, 受療圏は広範囲に及んでいた。 しかし, 病院より半径 $15 \mathrm{~km}$ 以内に居住している者 89 名中, 75 歳以上の高齢者群は，28\%であるのに対し，
$15 \mathrm{~km}$ 圏外から通院している者 29 名中, 高柃者群は 17\%であった。一方 ADLでみると， $15 \mathrm{Km}$ 圏内では $11 \%$ が要全面介助群であるのに対し， $15 \mathrm{~km}$ 圏外の要 全面介助群は， $7 \%$ であった。 また， $10 \mathrm{~km}$ 圏を越える 之, 高齢者群・ADL 全面介助群とも, 家族が仕事や家 事を 1 日休んで自家用車又はタクシーで送迎してお り，付添う家族の負担が予想された。

まとめ：通院負担を増す要因の一つに通院距離があ ク, 特に患者の高柃化, 病状の進行に伴い, 考虑すべ き点である事が確認された。

なお本研究は，笹川医学医療研究財団の研究助成金 を得て実施されたものである。

295. 要介護老人に対する在宅・地域ヶアー古河市 （茨城県）における実態調查よりー

筑波大社会医学系

江口 清

目的：古河市(人口約 5 万 8 千人)では，「福祉の森」 計画と名付けて, 地域での保健・医療・福祉を一体化 したシステムづくりを進めている，対策の急がれる在 宅要介護老人への適切な対応を検討するため, 基礎資 料作成の一環として以下の実態調査を実施した。

対象と方法：調査期間（平成 2 年 4 月〜 8 月）まで に在宅要介護老人として同市に登録されていた 124 人 より，訪問前に死亡，入院，転出した例を除き，さら に調査について承諾の得られた 100 人（男性47人，女性 53 人，平均年齢 $81.6 \pm 6.4$ 歳）を対象とし，基礎疾患， 必身の状態，ADL，生活背景掞よびこれらに関連する 諸問題について, 同市保険衛生課とともに訪問調査を 行った.

結果と考察：基礎疾患では脳血管障害を含め循環器 系の疾患が最も多く, 脳血管障害は全体の $38 \%$ に認め られた，四肢のいずれかに中等度以上の麻疩のある例 が26\%, 寝返りにも介助が必要な重度の体幹機能障害 を呈する例が $24 \%$ 存在し，褛瘡併発例14例中 11 例が寝 返り要介助例であった，対象の $50 \%$ で，問題行動を含 め知的機能の問題が日常生活の支障となっていた。 $56 \%$ オ゙オッを使用していたが，尿意を訴えることが 出来ないのは $39 \%$ であった. Barthel index が20点末 満の例が $53 \%$ 存在し，32\%が同 index 0 点と判定され た。少なくとも座位をとり臥床していない時間が 3 時 間未満といら状況が $42 \%$ にられたが，医療上の理由 で安静を要すると判断されたのは $6 \%$ みであった。 主たる介護者の $88 \%$ が女性であり，全体の $75 \%$ ガ介護 について負担を訴えていた，日常の活動性を高めて廃 
用性の機能低下を防ぎ, QOL を向上させる機会を増や すためには，介護にあたるマンパワーの充足が必要で あり，従来福祉を基盤として来た対応は三次予防活動 としても重要な役割を有すると考えられ，さらに保 健・医療・福祉を一体化させたシステムは地域ケアを 展開するためにも最適であると考えられる。

\section{6. 老年者在宅酸素療法の検討 第 1 報：患者,家} 族教育の意義について

都老人医療センター呼吸器科

藤野 孝子, 後藤 秀世, 平塚 知子 水内 知子, 神野 悟, 桂 秀樹

寺井 裕二，木田 厚瑞

目的：慢性呼吸不全の高齢患者が増加している，在 宅酸素療法患者の quality of life (QOL) を把握する ため各患者の自宅を訪問調査することにより，在宅で の現状と問題点を介護, 看護の立場より明らかにした。

対象及び方法：当院に括ける在宅酸素療法実施中の 患者36件の調査を行った. 調査項目は, 1. 家屋状況(構 造, 立地, 周囲環境), 2. 介護, 看護からみた患者の 生活状態一般 (身体症状, ADL, 日課, 清潔, 食事な ぞ), 3. 患者・家族の理解度（酸素吸入, 内服状況, 機械管理），4. 家族状況（家族構成，介護者の状況）, 5. QOL 調査, 6. 長谷川式簡易知的精神機能評価ス ヶール (7. CMI (Cornell Medical Index), 8. MAS (Manifest Anxiety Scale)，9. 写真撮影. 結果：家屋 状況は $86 \%$ \% 2 階建て以上で, 家屋内には段差が必ず あった。患者の生活状態は ADL は $88.9 \%$ は自立して いるが，趣味も無く終日テレビを見ながら臨床しがち が圧倒的に多かった。患者の介護者が一人のみの場合 が $67 \%$ ，妻，嫁，娘が主たる介護者であった。患者の 理解度は $74.3 \%$ が知的精神機能は subnormal 以上で あった、CMI はIII+IV群が $67 \%$, MASはI + II群が $70 \%$ と高度の不安傾向を示した。

考察及び結論：在宅酸素療法の患者の多くは知的理 解度も高く, ADL も自立している. しかし, QOL は在 宅導入により必ずしも拡大されて抢らず，また疾病に 上る不安傾向が療養生活に大きく反映されていた。 QOL 拡大, 不安の軽減には在宅導入前より患者, 家族 の問題を把握し, 患者個々にあった教育・支援が必要 であると考えられた。

297. 痴呆老人の症状と介護者負担感との関係に対 するンーシャル・サポートの緩衝効果の検討
都老人総合研究所精神医学研究室

新名 理恵, 矢富 直美, 本間 昭

目的：ソーシャル・サポート（以下 SS 子略記）は, ストレッサーが個人にもたらす影響を緩衝・緩和する 効果を持つことが知られている。本研究では, 痴呆老 人の心身の症状をストレッサーとして，負担感を介護 者への影響としたときに, SS が緩衝効果を持つかどう かについて検討することを目的とした。

方法：本研究は，精神科医による戸別訪問形式の調 查の一部として実施された。分析対象者は調查時に痴 呆老人を介護していた 63 名（男 5 名，女58名，平均年 龄51.7歳）である。これらの介護者に対して，介護者 負担感評価尺度 (CBS), 介護者の受けている SS の状 況を測定する質問などへの回答を求めた. CBS は，9 領域の介護者負担感を測定する28の項目からなる尺度 である.SS は，介護援助者と介護代替者と介護に関す る相談相手の有無, 家族の情動的サポートの程度の 4 変数により測定された。痴呆老人の症状には, 訪問し た精神科医による 4 つの症状評価（ADL と失禁の程 度, 痴呆の重症度, コミュニケーション機能の程度) を取り上げた。

結果：SS の緩衝効果を検討するために, 各 CBS 下 位尺度得点を従属变数, 性別と年齢と各症状評価と各 $\mathrm{SS}$ 得点と, 各症状評価と各 SS 得点との交互作用項を 独立変数とした重回帰分析を行った．交互作用項が有 意であった場合, 各 SS 得点の高低 2 群の各々につい て各 CBS 得点を従属変数, 各症状評価を独立変数と して回帰分析し， 2 群の回帰直線の傾き之切片の有意 差検定を行った。痴呆老人のコミニュケーション機能 の低下がもたらす「社会的サポートの不足」負担感に は相談相手がいることが，「家族・親族間のトラブル」 負担感には家族の情動的サポートが，失禁が強さ起こ す「家族・親族間のトラブル」負担感には家族の情動 的サポートが，痴呆の程度が重いことがもたらす「家 族・親族間のトラブル」負担感には相談相手のいるこ とが，各々緩衝効果を持っていることが示された。

298. 大学病院における外来診療と在宅ヶア一医療 と福祉サービスの連携について

東京大リハビリテーション部 江藤 文夫

同 老年病学教室

\section{飯島 節, 溝口環}

和田 博夫, 折茂 肇

大学病院外来に扮ける在宅ヶアの現状と問題点を明 
らかにする目的で，各種福祉サービスの利用ないし受 給状況を調查し，さらに 3 年以上の外来診療継続後に 診療を終了した過去 2 年間の自験例について，その契 機を検討した。

神経外来通院中で, 初診例を除く老年患者連続100例 を対象として，再診時に面接による質問紙法により， 現行の一般的な在宅福祉サービス 20 項目に関する知識 の有無, 利用ないし受給の有無, それらの情報入手源, 希望するサービスなどについて調査した，対象患者の 性別は男性44例, 女性56例, 平均年龄73.4歳, 通院診 療期間は 1 年末満が 9 例, 5 年以上が59例, 居住地域 は東京 23 区内が 69 例，都下が 7 例，他県が 24 例であっ た。

福祉サービス項目の情報普及度は老人クラブ $(78 \%)$ など50\%以上は 5 項目のみで, 利用度は老人クラブ (12\%)を除いてすべて $10 \%$ 未満で，大半は $5 \%$ 未満で あった。情報普及度を都内と他県在住者とで比較する と, 家庭奉仕員, おむつ等の支給に関して前者で有意 に大であった。これらの情報入手源としては区(役所) の広報によるものが最も多く(39件), 病院職員による ものは 6 件のみであった。 身体障害者手帳所有者は 17 名あった。一方, 外来診療終了者は 20 例あり（終了時 平均年齿 79.1 歳, 平均診療期間約 9.4 年), その契機は 死亡によるもの10例など医療に関するものの他に, 通 院介助を含めた介護条件の変化あるいは不都合による ものが 7 例あった。いずれも在宅ヶアにおける個別の 問題が含まれた。

外来診療の継続を必要とする老年患者の在宅ヶアに おいては福祉サービスの有用性が期待されるが，供給 の体系が医療とは異なることから情報不足の可能性が 示唆された。 福祉サービスとの連携のため, さらに大 学病院と地域医療機関との連携を円滑にするためにも 専門職種の配置が望まれる。

\section{9. 慢性疾患患者における在宅療養阻害因子の検} 討

$$
\begin{aligned}
& \text { 聖マリアンナ医大・第三内科 } \\
& \text { 丸山 啓子, 原 良太郎, 平山 俊和 } \\
& \text { 米田 直人, 高橋 洋一, 染谷 一彦 } \\
& \text { 同 公衆衛生学教室 } \\
& \text { 山村 行夫 }
\end{aligned}
$$

医療の進歩と人口の高齢化に伴い, 慢性疾患患者が 増加している. 患者の Quality of Life の向上のために も，在宅療養の意義は大きい. しかし種々の原因によ り在宅療養が困難となり, 長期入院を余儀なくされて
いるケースをよく経験する，我々は当科に入院した神 経系慢性疾患患者を対象に，在宅療養を阻害する医療 的，社会的因子を検討した。

過去 3 年間に当科に入院した神経系慢性疾患患者 37 名を対象とした。うち男性19名，女性18名で，疾患別 分類は脳血管障害 24 名, 变性疾患11名, 中枢神経系腫 瘍 2 名であった。

在宅療養導入を阻害すると考えられる医療的，社会 的因子を設定し，導入に有利と思われる状態ほど高得 点になるように各因子を 3 段階に分類した。臨床症状 の因子は症状, 年齢, 意識レベル, 精神症状, 神経所 見, 合併症で, ADL の因子は姿勢保持, 移動, 整容動 作, 入浴動作, 着衣動作, 排泄動作, 食事動作とした。 社会的条件の因子は，外的条件として介護者，経済状 況, 住居, 個人的条件として患者自身の疾患の受容度, 目的意識の程度, さらに対家族, 対他者, 対スタッフ との人間関係をあげた。

各症例の転帰の評価は, 在宅可能例では, 3 カ月以 上在宅療養が継続しているもの 4 例，入院を反復する が在宅療養に復帰しているもの 13 例, 在宅療養を目的 としリハビリテーション病院へ転院したもの 5 例で, 在宅不可能例では, 現在入院中もしくは死亡退院と なったもの 3 例, 在宅療養を目的とせず転院となった もの 10 例, 3 力月以内に再入院となり在宅療養に復帰 できなかったもの 2 例であった。

我々は可能例と不可能例で各因子の合計値が高値で あったものが在宅療養導入が可能か否かに大きく関与 する因子であると考元た。その因子は臨床症状では球 麻瘴の存在や意識レベル, ADL では姿勢保持や整容動 作, 着衣動作, 社会的条件では対家族の人間関係であっ た。

\section{0. 沉発性レヴィー小体病の臨床・病理学的検討} 東京医科歯科大神経内科

$\begin{array}{lrr} & \text { 和田 } & \text { 義明, 塚越 } \\ \text { 浴風会病院病理 } & \text { 河崎 } & \text { 博 } \\ \text { 同 内科 } & \text { 大友 } & \text { 英一 } \\ \text { 東京大精神科 } & \text { 松下 } \text { 正明 }\end{array}$

近年, 汎発性レヴィー小体病 (DLBD) は痴呆を示す 疾患群として注目され，その特徵が明らかにされつつ ある。 今回自験 8 例の DLBD につき臨床的, 病理学的 検討を行なった。典型的なパーキンンン症状の経過の 後, 痴呆を示した例（パーキンンン病十痴呆）は除外 した。 
結果 : <臨床的検討>発症は平均 74 歳, 経過は平均 約 4 年と予後不良の疾患であり, 初発症状は, 健忘, 幻覚・譫妄, 軽度の歩行障害が多く, 初期には痴呆症 状よりむしろ幻覚, 譫妄が主体の精神症状を示し（8/ 8 例), 時に抑椟的となる ( $2 / 8$ 例). 比較的早期に（約 3 年）ねたきりとなり誤嚥などで死亡にいたる。パー キンソン症状（歩行障害, 振戦, 固縮) は病期のいず かに呈することはあるが (5/8例) 典型的症状は認めな かった．著明な起立性低血圧を 1 例で認めた.

＜病理学的検討＞従来の報告のごとくレヴィ一小体 は脳幹, 基底核, 大脳皮質に広範に分布し, 大脳皮質 では島回，嗅内野，鈎回，海馬傍回，带状回に多く出 現していた。視床下部，無名質，扁桃核もレヴィー小 体が多くみられた，老人斑は全例で中等一高度に出現 していたが，アルッハイマー原線維変化は海馬周辺を 除いては軽度出現の例が大半であった。無名質, 青斑 核の神経細胞脱落は中等一高度であったが，黒質は一 定の傾向はなかった。これらに加充，嗅内野，鈎回， 海馬傍回，扁桃核のグリオーシス，神経細胞脱落が目 立つ例が多く，部分的海綿状態を示す例も多かった。 側座核の類球体もほぼ全例でみられた。

結語：DLBD は予後のきわめて不良な病態であり， 老人では頻度としては決して少なくない。痴呆, 精神 症状の原因として，無名質，皮質神経細胞の変化のみ ならず，嗅内野，鈎回，海馬傍回，扁桃核，側座核と いった辺縁系の関与が示唆された。

\section{1. 老人脳における血管アミロイド沈着の検討} 一老人斑, 神経原線維变化との関連について一

$\begin{array}{ll}\text { 浴風会病院病理 } & \text { 河崎 博 } \\ \text { 同内科 } & \text { 大友 英一 }\end{array}$

目的：老人脳に括ける血管アミロイド沈着の意義に ついて老人斑と神経原線維変化との関連から検討し た.

方法：浴風会病院に打ける188連続剖検例（平均年 齢 $=83.8 \pm 7.7$, 男 : 女 $=75: 113 ）$ の脳を神経病理学 的に観察した. 各症例の左側中側頭回之後頭葉外側の 髄膜血管のアミロイド沈着の比率を, コンゴーレッド 染色切片に打いて各部位50血管当りのアミロイド沈着 血管を数えることによって求めた。また, メテナミンー ボデイアン染色切片において同部位の皮質全層にわた る一定区域内の老人斑と神経原線維変化の密度を求め た。全症例をアルッハイマー型老年痴呆群 (57例) と その他の群 (131例) とに分けて，上記の病変について
比較検討した.

結果：髄膜血管のアミロイド沈着は中側頭回では

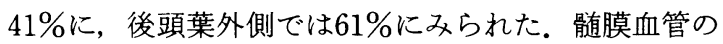
アミロイド沈着の程度は年齢と相関しなかった。老人 斑, 神経原線維変化についても年齢との相関はなかっ た. 中側頭回, 後頭葉外側各々の部位において, 老人 斑と神経原線維変化との間, 血管アミロイド沈着と老 人斑との間，そして血管アミロイド沈着と神経原線維 变化との間の順に高い関連性がみられた。アルッハイ マー型痴呆ではその他の例に比べ，上記 2 部位それぞ れに抢いて血管アミロイド沈着, 老人斑, 神経原線維 変化のどれも有意に多くみられた。

結論：老人脳においては約 $60 \%$ の頻度に执いて髄膜 血管のアミロイド沈着がみられるが，年齢に従って血 管アミロイド沈着が増加することはなかった。血管ア ミロイド沈着は神経原線維変化よりも, 老人斑の出現 と高い関連性があった。アルッハイマー型痴呆群にお いては老人斑や神経原線維変化ばかりでなく, 血管ア ミロイド沈着も有意に多くみられた。

\section{2. 老人施設内に於けるアルツハイマー型痴呆の 臨床病理学的検討}

名古屋市厚生院内科

稲垣 俊明，野倉 一也，新美 達司

山本 俊幸, 三竹 重久

同 病理立松 正樹 名古屋大病理部橋詰 良夫

目的：老人施設内のアルッハイマー型痴呆の実態を 明かにするため, 剖検で診断確定例について, 臨床病 理学的に検討をした。

対象と方法：対象は，生前臨床的に痴呆拈よび原因 疾患の診断された症例で, 過去 3 年間に剖検で確認さ れたアルッハイマー型痴呆（高度老年変化は Bodian 染色で, 海馬 H1 H3に100個以上の原線維変化または 前頭葉皮質に 100 倍視野で10個以上の老人斑) 26 例（男 3 例，女 23 例，死亡時年齢 $75 \sim 98$ 歳，平均 86.5 歳）で ある。

結果：同時期に痴呆と診断され，剖検された症例の なかで，アルッハイマー型痴呆は $25 \%$ であった。臨床 診断はアルッハイマー型痴呆 $84.6 \%$, 脳血管性痴呆 $7.7 \%$ ，その他 $7.7 \%$ であった。罹病期間は 7 カ月〜 15 年，平均 6.9 年であり，施設内入所後の痴呆の発症は $46.2 \%$ であった。骨折，他の合併症などによる臨床期 間は 0 カ月〜 8 年, 平均 2.5 年であった。神経症状は前 
頭葉徵候 $84.6 \%$, 歩行障害 $92.3 \%$, 失禁 $84.6 \%$, 屈曲 性対麻痺 $38.5 \%$ であり, 精神症状は記憶障害 $100 \%$, 計 算力障害 $100 \%$, 不穏・興奮 $84.6 \%$, 異常行動 $76.9 \%$ で あった。直接死因は肺炎 $19.2 \%$, 心笳梗塞 $15.4 \%$, 他 の心疾患 $11.5 \%$ で, 残りが競合死, 消化管出血などで あった. 病理学的には軽度の脳血管障害（痴呆を起こ さない程度）の合併例が $46.2 \%$ あったた，高度老年変 化と痴呆の程度（柄澤の判定基準）は，前頭葉皮質の 又（頻度 $42.3 \%$, 平均年㱓 84 歳, 軽度 $18.2 \%$, 中等度 $18.2 \%$, 高度 $63.6 \%)$, 海馬のみ $(19.2 \%, 88$ 歳, 中等 度 $20 \%$, 高度 $80 \%)$, 両者の合併 $(38.5 \%, 88.4$ 歳, 高 度 $100 \%$ であった。

結論：老人施設内のアルツハイマー型痴呆は, 入所 後の発症が約半数であり, 罹病期間, 臥床期間が比較 的長期であり，直接死因が肺炎，心疾患で約半数をし めた。病理学的には, 脳血管障害の合併を認める症例 があり, 高度老年变化が海馬, 前頭葉皮質にみられる 症例は, 全例痴呆が高度であった。

\section{3. 海馬 CA2のアルツハイマー原線維变化と加龄 の関係}

都老人研臨床病理 都老人医療センター1) 水谷 俊雄, 小林 康孝, 望月 英昭 吉村 正博, 山之内 博 ${ }^{11}$ 嶋田 裕之 ${ }^{11}$

海馬をCA4からCA1に分け，23歳から106歳までの コントロール158例, SDAT 14例, について調ベた. 外側膝状体を通る前額断の海馬をBiekschowskyHirano 法で染色し，1枚の切片について各部位の NFT の数をパーセントで表わした. その結果，1） 60 歳以降ではCA2の NFT は年齢と相関せず一定して いる，2）60歳以降でも各年代, 各部位にはNFT が全 く見られない人が必ずいる，3）CA2を除く部位の NFT は加齢とともに増加する, しかし，4）各部位で 出現頻度が統計学的有意差をもって大きく変る年代が あり, CA4, CA1では70～80歳, CA3は80～90歳以降 との間である,5）SDAT では, 年齢と相関しないCA2 を含む 4,3 にNFT が高頻度に出現する, ことが明ら かになった。

海馬の NFT はさまざまな研究から, 加龄とともに 増加することが知られており, 老年性変化のひとつの 指標である、しかし，部位別に調べた報告はいままで になく，今回の研究で部位によって異なることが明ら かになった.とくにCA2 (抵抗帯) では加齢の影響を 受けにくいことが推定され, しかもSDAT では逆に高
頻度に出現することが注目される。CA2は線維連絡が 最も分らない部分であるが，正常加齢と病的状態を考 える上で重要と思われた。なお，今回検索した部位や 染色法は最近多くの施設で行なっているポピュラーな ものであるが，それだけにNFT の量と老年性変化の 評価には慎重であるべきことが示唆された。

\section{4. 筋緊張性ジストロフィー症 (MyD)におけるア} ルッハイマー神経原線維変化 (NFT) の検討

東京大脳研病理, 現 東京医大老年科*

木内 章裕*, 大塚 成人, 難波 吉雄

中野 今治, 朝長 正徳

目的：MyDは遺伀的早老症の一つと考えられてい るが，中枢神経系の代表的な加齢変化である NFTに 関しては，少数の報告があるのみである。そこで我々 はNFTがこの疾患において一般的に出現するものな のか否かを明らかにすべく, MyD 7 例の脳内 NFTを 検索した。

症例および方法：MyD 7 例（35〜56歳）と, agematch した正常対照18例 (34〜58歳) の脳を検索した. 外側膝状体を含さレベルの冠状断で海馬, 海馬傍回, 新皮質である外側後頭側頭回の 3 つの部位を含む切片 を作製し，Bielschowsky 染色にてNFTを検索した。 50 歳代の 2 例では, 他の大脳新皮質, マイネルト核や 脳幹についても検索を行った。 また， NFT・老人斑の 確認のため, 抗 $\mathrm{tau} ・$ 抗 $\beta$ ポリクロナール抗体を用いた 免疫染色もあわせて行った。

結果执よび考察：正常対照例の大多数ではNFTは いずれの部位にも全く認めず，少数例で少数見られた のみであった.MyDでは全例で海馬, 海馬傍回に NFTを認めた. 外側後頭側頭回では50歳代の 4 例で のみ少数の NFT が観察された. 海馬傍回ではNFT は年齢と共に増加し，50歳代の 4 例全てで多発してい た. 最年長の症例では, 海馬にも多数の NFTを認め た. 側頭葉以外に他の大脳新皮質も検索した 2 例では, その部分の NFT の出現数は外側後頭側頭回のそれと ほとんど差がなかった。この 2 例ではマイネルト核, 鉤回, 偏桃体, 青斑核, 縫線核にも NFT が認められた. 老人斑はいずれの症例にも認められなかった。抗 tau・ 抗 $\beta$ 免疫染色でも至济同様の結果が得られた。

以上より以下の 2 点が結論できる. (1) MyD では正 常加齢より早期に海馬傍回を中心にNFT が出現す る. (2)これは, 本疾患の種々臓器に見られる早老変化 の一つであると考えられる。 
305. アセチルコリンェステラーゼ陽性老人斑一 $\beta$ 蛋白免疫染色との比較

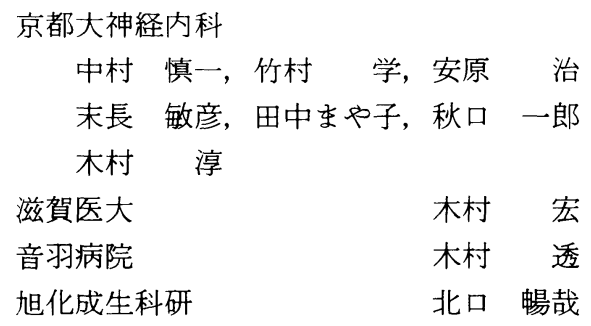

目的：抗 $\beta$ 蛋白抗体をもちいた免疫組織化学によ り $\beta$ 蛋白沈着の形態的多様性が明かにされてきた (Yamaguchi ら，Wisniewski ら)。それらの報告によ ると，いわゆる classic plaque, primitive plaque に加 え, diffuse type, subpial ribbon-like infiltration, granular deposits in the white matter，小脳分子層と 基底核の diffuse deposits, Purkinje 細胞層の starshaped deposits などが存在するという。一方, 老人斑 にアセチルコリンェステラーゼ (AChE) 活性が存在 し, neurite とアミロイドが染色されることが報告され ている. 今回, 剖検脳をもちいて, AchE 染色と $\beta$ 蛋 白免度染色を比較し， $\mathrm{AChE}$ 陽性老人斑に打ける形態 的多様性の有無を検討した。

方法：潅流固定した老人剖検脳の海馬, 側頭葉皮質 の凍結連続切片 $(20 \mu$ 厚)を $\mathrm{AChE}$ 組織化学 (Tago ら) と $\beta$ 蛋白免疫組織化学で交互に染色し, 対応する部位 を写真撮影し比較検討した。

結果：(1) AChE 活性は神経線維, 一部の神経細胞, 老人斑，神経原線維変化に認められた。 (2) $\mathrm{AchE}$ 活性 は老人斑 neurite, classic plaque に加兄て, diffuse type, subpial ribbon-like infiltration, granular deposits in the white matter, Drusige Entartung 同一形態の構造にも認められた。隣接切片の対応する 部位の $\beta$ 蛋白免疫染色の所見から, これらは $\beta$ 蛋白の 沈着部位と考えられた。

結語：AChE 陽性老人斑には $\beta$ 蛋白免疫組織化学 でみられる老人斑の形態的多様性と同様の現象があ る.このことは $\mathrm{AChE}$ と老人斑アミロイドとの密接な 関連を示唆している。 さらに, $\mathrm{AChE}$ 活性はアミロイ ド沈着の早期より出現している可能性がある.

\section{6. 高齢男性剖検脳の形態像と痴呆}

愛知医大加齢医科学研究所

名古屋市厚生院 ${ }^{1)}$

佐藤 秩子, 伊藤 美武, 宮石 理
甲谷 憲治, 水野 俊昭, 田内 久 稲垣 俊明 ${ }^{11}$ 立松 正衛 $^{1}$ 新美 達司 ${ }^{11}$ 山本 俊幸1

さきに私どもは56歳から101歳までの高齢女性剖検 例100例の脳, とくに海馬領域の病理形態学的検討を行 い, これらの成績と臨床的な痴呆の種類, 程度との関 連を対比検討し，その結果を本学会誌に報告した。

今回は, 71歳から99歳までの男性50例を対象として 同様の検索を行い，女性例との対比も行ったので報告 する.

海馬領域の顆粒細胞層, 錐体細胞層の神経細胞数は, 加齢とともに減少する。79歳以下の例では, 錐体細胞 層に虚血性の小軟化巣が散在するのをみることがしば しばであったが，必ずしも臨床的な痴呆の症状とは関 連していなかった。痴呆の種類については, 血管性 $14 \%$ （13\%）（）内に女性例に拈ける\%を示す。フルッハ イマー型老人性 $8 \%$ (22\%), 混合型 $14 \%$ (11\%)であっ て，アルッハイマー型が少ないのが特徴であり，男性 では一般に痴呆の程度も軽い。アルッハイマ一原線維 変化, 老人斑の発現は女性例に比して軽度で，とくに 後者の発現が軽度であったのは，すでに女性例の検討 において考察したよらに，老人斑の発現とアルッハイ マー型痴呆とは, 密接な関連のあることを確かめる一 つの事実の追加とも考光る。

本質的な老化の形態像と考号られる神経細胞数の減 少は, 男女, 痴呆とは関係なく加齢とともに進行する が，男女の病的変化の発現には差があり, 海馬領域に 限っても, 病像の修飾により, 形態学的所見にかなり の男女差が認められた。神経細胞内の自家蛍光色素顆 粒の発現は90歳代でむしろ減少する細胞が多かった。

\section{7. 原爆被爆者脳における老人性变化 (III) 一嗅球} および海馬, 海馬傍回における検討一

長崎大原爆資料センター精神科 ${ }^{11}$

国立長崎中央病院 ${ }^{2)}$, 九州大脳研病理 ${ }^{3)}$

岸川 正大, 井関 充及, 西村 美香

近藤 久義, 川口哲 ${ }^{1}$ 藤井 秀治 ${ }^{2}$

関根一郎, 辛 龍雲 ${ }^{3)}$

嗅脳系の末梢側と海馬について原爆被爆と老化促進 の有無といら点から検討した. 嗅球は水平断連続切片 乙し, 通常染色, 抗 $\beta$ 蛋白抗体, 抗 $\tau$ 抗体を用いて検 討した。嗅球の老人斑 (SP) は被爆群, 対照群とも確 認できず，神経原線維変化 (NFT) は前者14例中 4 例 (28.6\%)，後者14例中5例 $(35.7 \%)$ に認めた。海馬の 
SP は被爆群のみ 2 例（14.3\%）に, NFT は両群とも 7 例 (50\%) に認めた。海馬傍回の SP は被爆群の 3 例 (21.4\%), 対照群の 2 例 (14.3\%) に認め, NFT はそ れぞれ 9 例 $(64.3 \%), 10$ 例 $(71.4 \%)$ に認めた。

\section{8. 老年者ウェルニッケ脳症の検討一剖検例につ} いてー

\section{都老人医療センター神経科}

横手幸太郎, 山之内 博

同 病理部 嶋田 裕之

都老人総合研究所臨床病理部 水谷 俊雄

緒言：ビタミン B1の欠乏により生ずるとされる ウェルニッケ脳症は，アルコール常用者に発症する例 が有名であるが，最近では，非アルコール摂取者にも 少なからず見られることが注目されている.今回,我々 は, 剖検時に確認された老年者のウェルニッケ脳症例 について，その臨床像の特徵を検討した。

方法：最近18年間の当院に括ける剖検例のらち, 脳 の病理学的所見からウェルニッケ脳症と診断された 5 症例を対象に，発症に至る背景，臨木上の特徵につい

て検討した。

結果：症例は 5 例とも女性，年齢は63歳から 74 歳で あった．剖検脳の検討では, 全例とも典型的なウェル ニッケ脳症の病理像を呈していた。基礎疾患は神経疾 患, 消化器系疾患, 代謝性疾患, 悪性腫瘍など多岐に わたっていた．生前にウェルニッケ脳症の診断を受け ていたものは僅かに 1 例だった。臨床症状としては, 意識障害が 4 例, 眼球運動障害, 運動失調が各 2 例に 認められたが，これらすべて(いわゆる古典的 3 主徵) を揃えたものは 2 例であった。 その他，発熱，四肢筋 力低下，頻脈，下痢などがみられた４４例では何らか の理由により経口摄取が困難であった。 5 例とも補液 療法を施行されていたが， $5 ち 44$ 例ではビタミン剂が 投与されていなかった。いわゆる大酒家は 1 例の及で あった。

結論：老年者のウェルニッケ脳症は決して稀ではな い。アルコールとは無関係のものが多く, 低栄養状態 を背景とした長期輸液例に多い，症状は非特異的であ り, 意識障害の頻度が高い. いわゆる 3 主徵の確認さ れたものは少なく,臨床診断は必ずしも容易ではない。 老年者に原因不明の意識障害を見た場合，鑑別診断の 一つとしてウェルニッケ脳症を忘れてはならない。

\section{Cystatin $\mathrm{C}$ の沈着を伴う cerebral amyloid}

angiopathy (CAA) の enzyme linked immunosorbent assay（ELISA）法による診断と免疫組織化学的 検討

$$
\text { 島根医大第三内科 }
$$

$$
\begin{aligned}
& \text { 下手 公一, 藤原 茂芳, 小林 祥泰 } \\
& \text { 今岡か扣る, 長井篤, 恒松徳五郎 }
\end{aligned}
$$

目的：アイスランドで hereditary cerebral hemorrhage with amyloidosis（HCHWA）が報告され，そ のアミロイド蛋白は cystatin C の variant であること が知られている。既に我々も cystatin C の沈着を伴う CAA を本邦で初めて報告した。今回は，ELISA 法で 髄液中の cystatin C を測定し，一部の脳出血例で免疫 組織染色を行った。

対象：脳出血34例（多発性脳出血 2 例，皮質下出血 18例, 視床出血 5 例, 被殼出血 8 例, 放線冠出血 1 例) とコントロール群45例（脳梗塞27例, 筋萎縮性側索硬 化症 5 例, パーキンソン病 4 例, SDAT 6 例, epilepsy 3 例）を対象とした。

方法：抗 cystatin C monoclonal 抗体, 抗 cystatin C polyclonal 抗体を用いて, ELISA 法により䯣液中の cystatin C の定量を行った。手術標本が得られた脳出 血 2 例に拈いて, Avidin Biotin Complex (ABC) 法 を用いて免疫組織染色を行った。

結果: 多発性脳出血 2 例, 皮質下出血16例, 視床出 血 2 例に打いて, 髄液中の cystatin C の濃度がコント ロール群に比して低值を示し，その中で高血圧を伴っ ていたのは 2 例のみで, 臨床的に CAA が疑われた。そ の他の脳出血では全例に高血圧を認め, コントロール 群と同様に cystatin C は高値を示した。 cystatin C が 低值を示した皮質下出血 2 例の免疫組織染色では， 2 例之も抗 cystatin $C$ 抗体及び抗 $\beta$ 蛋白抗体に脳軟膜 血管が陽性に染色された。

考案：CAAの可能性の高い脳出血例の䯣液中の cystatin C が低值を示し，一部の例に打いて免度組織 学的に cystatin C の沈着を伴う CAA であることが確 認され，本アッセイ系がCAA の有力な診断法となり 得ることが示唆された。

310. 脳血管障害患者における血清および血将 $\mathbf{N}$ acetyl- $\beta$-D-glucosaminidase (NAG) 活性值とその臨 床的意義

聖マリアンナ医大第三内科

都立医療技術短大内科1)

前原 真司，加藤 麻子，佐藤 豊明 
川上 正人，栃木捷一郎 ${ }^{1)}$ 染谷 一彦

目的: N-acetyl- $\beta$-D-glucosaminidase (NAG) は lysosome に局在する分子量約12万の酸性水解酵素の 一つで, 臓器特異性は乏しいが, 組織が傷害されると 組織の酸性化により活性化され尿中, 血中一遊出する. また, NAG 活性の変動は尿中と血中とで異なること が知られている. 今回我々は, NAG 活性の比色測定法 の人工基質である MCP-NAGを用いて急性期和よび 慢性期脳血管障害患者 (CVD)の血清および血浆 NAG 活性を測定し，その臨床的意義を検討した。

対象之方法: 急性期 CVD 35例 (男16例, 女19例), 平均年齢70歳を対象とした。CVDの内訳は脳梗塞29 例, 脳出血 6 例で, 全例入院時にCT スキャンを施行 し,ささらに 7 日目, 14 日目にも施行して脳浮腫の推移 を検討した。血清 NAG 用の採血は入院第 $1 ， 3 ， 7$, 14日目に行い, NAG 活性の頂值と経時的変化を検討 した. そして, 神経症状の推移, CT 上の病巣の大きさ および脳浮腫の程度と血清 NAG 活性の動態との関連 を検討した。同様に発症後 1 力月以上経過した慢性期 CVD 46例についても血清 NAG を測定し, 急性期群と 比較した。約半数例では血浆 NAG 活性の变化子検討 した。

結果・結論 : 急性期 CVD の血清 NAG 活性の頂値 は14.1 $13.5 \mathrm{U} / l$ (mean $\pm \mathrm{SD})$ で, 対照群 $8.2 \pm 2.0 \mathrm{U} /$ $l$ 打よび慢性期群 $9.8 \pm 2.1 \mathrm{U} / l$ に比べて有意に高值を 示した (いずれも $\mathrm{p}<0.001)$. 脳梗塞, 脳出血ともに高 值で, 両群間に有意差は認めなかった. CT 所見上, 病 巣が大きい群は小さい群に比べて有意に高値を示し た. 特に, 急性期死亡例, 脳浮腫の著明な例では高値 であった。一方, 慢性期群では対照群と有意な变化は 認めず, 病巣の大きさによる差異も認めなかった。し かし, 糖尿病 (DM) を合併した慢性期 CVD の血清 NAG 活性は, 非 DM 例および対照群に比べて有意に 高值を示した。今回の研究成績より, 血清 NAG 活性は 急性期 CVD の脳損傷を反映し, その経時的変化は神 経症状の予後判定に有用である可能性が示唆された。

\section{1. 高齢者脳梗塞の病態一高血圧症の及ぼす影響}

国立埼玉病院神経内科

国療宮城病院理学診療科 ${ }^{11}$

衣川 秀一, 小玉 隆一, 笹生 俊一1)

目的：80歳を越える高齢者では高血圧を治療して も, 脳・心合併症の頻度は低下せず, 血圧の高い方が
むしろ長寿であったとの報告もみられる。そこで，80 歳以上の脳梗塞患者に抏いて, 高血圧が生命予後など 病態にいかなる影響を及ぼしているかを知りたい。

方法：1985年から1988年の 4 年間に入院した全脳卒 中 1,533 例の $5 ~ 500$ 歳以上の脳梗塞 90 例を対象に, 既往 歴技よび入院現症より高血圧のある群 $(\mathrm{CIH}) 55$ 例と, 無い群 (CI) 35例に分け, 各種臨床所見を比較検討し た。

結果打よび結論：(1)発症平均年齢：CIH は83.4 3.1歳, CI では83.7 3.2 と両群間に差はない. (2)男女 比：CIH では男32例, 女23例で CI では男20例, 女15例 と両群とも 4 対 3 とやや男性が多い. (3)入院時意識障 害程度：3-3-9度方式で評価し比較すると, $\mathrm{CIH}$ では 意識清明例が 22 例 $40 \%$, I 桁は 21 例 $38 \%$ と両群で約 8 割を占めている. II 桁, III桁のものは各々 8 例, 4 例 で, 合わせて 12 例約 $20 \%$ となっている. CI 群でも意識

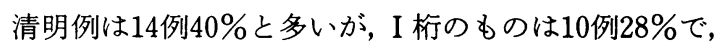
II 桁, III桁のものは各々 6 例, 5 例で合計約 $31 \%$ 之 $\mathrm{CIH}$ に比し意識障害の強いものがやや多い. (4)臨床所 見打よびCT 上の病変部位: $\mathrm{CIH}$ では天膜上病変が 45 例 $82 \%$ と大半を占めている. CI でも天膜上病変は 22 例 $63 \%$ と多いが，CT 上明らかな病变が見られず脳幹 病変の可能性を示唆するものが 13 例 $37 \%$ と多い. (5)予 後: $\mathrm{CIH}$ では死亡が 15 例 $27 \%$ と最も多い. 部分介助も 13 例 $24 \%$ と多く，次いで，寝たきりの 10 例 $18 \%$ と予後 不良のものが多い，一方，CI では家庭内自立したもの が10例 $29 \%$ と最も多い。次いで，部分介助の 8 例 $23 \%$ と CIH に比し予後良好であった. しかし, 死亡も 8 例 $23 \%$ と比較的高率である。両群とも心不全, 肺炎など の合併症死が多い，以上より，80歳を越す超高齢者の 脳梗塞では高血圧を伴わないものは, 高血圧合併例に 比し, 脳幹病变が高頻度である可能性が高く, 予後は 良好である. 両群とも死亡率は高く, 合併症死が多い。

\section{2. 老化現象に関する研究一第75報一脳主幹動脈} 狭窄病変に及ほす危険因子の検討

国立岡山病院, 岡山大第 2 内科 ${ }^{1)}$

国療南岡山病院 ${ }^{2}$

石岡 達司, 神坂 謙 ${ }^{11}$ 細井みち子11

木村 郁郎 ${ }^{1)}$ 三島 康男 ${ }^{2}$ 木畑 正義 ${ }^{21}$

目的：脳血管写を用いた脳血管障害の危険因子に関 する研究では対象を脳梗塞としているために自然に高 齢者が対象となり若年期での危険因子の影響を評価す ることが困難となっている，そこで，脳血管障害に限 
らず脳血管写により評価された脳主幹動脈の狭窄病変 と危険因子の関連について検討した。

対象ならびに方法：1989年 4 月より1990年11月の間 に頸動脈写を施行した男性34名, 女性33名の合計67名 を対象とした，対象の平均年齢は 58 歳（13～80歳）で あり, 疾患は脳動脈瘤31名, TIA 10名, 脳血栓症 9 名 などであった，危険因子として脂質代謝では血清脂質 (TC, TG, HDL-C, LDL-C), 血清アポ蛋白(ApoA-I, ApoA-II, ApoB, ApoC-II, ApoC-III, ApoE), 糖代 謝では FBS, HbAlc, 1 日尿中 C-peptide, 血清生化 学検查では ALB, UA, また, 年齢, 血圧, 心電図上 の左室肥大, 肥満度 (BMI), 契煙, 飲酒を用いた。

CAG 所見は総䅡限脈, 内頸動脈, 外頸動脈, 前大脳 動脈, 中大脳動脈の 5 主幹動脈を 2 方向以上より観察 しltalian Multicenter Studyのスコアシステムに準 じて各々の血管狭窄度を数量化し, 重回帰分析により 各因子の影響の大きさを検討した。

成績 : 主幹動脈の狭窄度は抎張期血圧, 動脈硬化指 数, 䒜煙, ApoB/ApoA-1, ApoA-1, 収縮期血圧, 年 齢の順に高い正相関を示し, ApoA-I は負相関を呈し た. 次に，65歳以上群と未満群の分類に於ける検討で は以上群で蓄尿中 C-peptide が負の相関を呈した以外 ほ注以上群, 未満群ともに同様な傾向を示した。しか し，危険因子の強さを回帰係数の大きさでみれば以上 群に比較して未満群では各危険因子の影響力が明らか に強力であった。

老年医学的意義：脳血管障害に対する危険因子の加 齢による影響力の变化を検討したが，危険因子に対す る治療開始時期に関し示唆に富む結果と考兄る.

\section{3. 多発性脳梗塞に伴う歩行障害, 球症状の MRI における検討（第 2 報）}

聖マリアンナ医大第 3 内科

柴田 洋一, 平山 俊和, 中里 守宏
赤沼 卓, 米田 直人, 荒井 義彦
辺見 元, 高橋 洋一, 染谷 一彦

目的：MRI 上多発性小梗塞を認めても何ら神経症 状を示さない例が認められる，その一方で歩行障害， 仮性球麻疸, 痴呆症状などを種々の程度に呈する例も ある. 今回われわれは，MRI 上多発性小梗塞を認めた 患者を歩行障害群, 仮性球麻瘒群, 無症候群の 3 群に 分け，その病巣分布を比較検討した。

対象・方法：スピン・ェコー法 $\mathrm{T}_{2}$ 強調画像, 水平断 $8 \mathrm{~mm}$ スライスを用い, 明らかな運動麻瘦, 長径 $15 \mathrm{~mm}$
以上の梗塞巣を有する例を除外した．対象は 45 ～86歳 の34例で, このうち歩行障害群は 7 例(平均 $74.3 \pm 5.9$

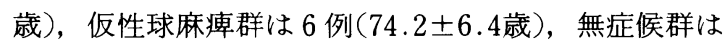
21 例（62.5 \pm 10.5 歳）であり, 各群での障害部位, 程 度を年齢も加味し比較検討した。

結果：1）歩行障害群, 仮性球麻㿎群は, 全て65歳以 上であった，2）無症候群では，65歳以上11例(71.4 5.0 歳), 65 歳未満 10 例 ( $52.9 \pm 5.2$ 歳) で65歳以上で側 脳室扗大, 大脳萎縮, 半卵円中心, 放線冠での高信号 域が多く認められた。 3）65歳以上においては，無症候 群に比べ歩行障害群では側脳室・第 3 脳室拡大, 傍側 脳室高信号域の程度が強く，また基底核領域の高信号 域を多く認めた。仮性球麻疸群では基底核領域の高信 号域を多く認めた。

結語: 加齢により脳室拡大, 大脳萎縮, 傍側脳室 大脳白質の高信号域の増加が認められるが，さらにそ の程度の強いものに症状が発現してくると思われる.

\section{4. 高跉者脳血管障害患者における Waller 变性} について

\author{
名古屋市総合リハビリテーションセンター \\ 神経内科日比野敬明, 紙本薰 \\ 蒲沢 秀洋, 松原 充隆
}

目的：脳梗塞，脳出血などの脳血管障害において， 大脳半球の皮質運動や，錐体路線維が広範に傷害され た患者の慢性期 MRI T2強調画像にて同側の大脳脚, 橋腹側に高信号域が認められる症例があるが，これは 錐体路のWaller 変性として種々の報告がある. 1989 年 12 月以降当院にて施行された脳血管障害患者の MRI を series で観察し, Waller 变性の有無と病変の 大きさ, 病変部位, 神経学的重症度を検討し, 併せて Waller 変性の出現時期についても検討した。

対象：脳血管障害患者123例(脳梗塞患者68例, 脳出 血患者55例）を対象とした。

方法：MRIは島津社製，1.5Tを用いた，T2強調画 像にて天幕上病変と同側の大脳脚及び橋腹側に高信号 域を認めた場合, 同側脳幹部の半側萎縮を認めたもの をWaller 变性有りとした。神経学的重症度は, 移動の 方法, 下肢, 腕, 手の Brunnstrom Stage で評価した。 結果：脳梗塞では，皮質枝梗塞の方が，穿通枝梗塞 より有意にWaller 変性を多く認めた。脳出血では, 被 殼出血, 視床出血ともWaller 変性を認める群では, 血 腫が内包後脚に及んでおり, 血腫量も有意に多かった。 神経学的重症度による検討では, 移動の方法の自立性 
の低いもの, Brunnstrom Stage の低いものに Waller 変性が多く認められる傾向があった. Waller 変性の出 現時期は, 発症後 3 力月上り脳幹部に高信号域を認め る症例が存在した。

考案：錐体路 Waller 変性は, 従来の CTscan では, 片側の脳幹萎縮として捉えられるだけであったが, MRIではより早期にWaller 変性の有無を捉えるこ とが可能である。慢性期脳血管障害患者の MRI にお いて, Waller 変性による高信号域が存在することを知 ることは, 多発性硬化症や脳幹部梗塞との鑑別に必要 であるばかりでなく, 患者の運動機能や ADL の予後 を早期に知る上で重要な所見と考兄られる。

\section{5. 慢性期脳血管障害に伴う二次变性一特に crossed cerebellar atrophy を中心ー}

東京医大老年科, 西武川越病院 ${ }^{11}$

新井 久之, 羽生 春夫, 佐藤 慶仁

金谷 潔史，清水 伸哉，勝沼 英字

藤田 龍一1) 友利 千之 ${ }^{11}$

目的：老年者の脳血管障害に続発する遠隔領域にみ られる二次变性のらち, 特に対側小脳半球の萎縮 (crossed cerebellar atrophy, 以下 CCA と略す)を中 心に, 神経放射線学的に観察しその病態に検討を加兄 た。

対象と方法：発症後 2 力月以降の慢性期脳血管障害 103 例 (年歯60～91歳, 一側大脳半球内出血 31 例, 一側 前, 中大脳動脈領域梗塞72例) を対象とし, X 線 CT に より CCAの有無を観察した。

結果: CCA は 9 例 (8.7\%) 飞認められ, 出血群 ( 3 例，9.7\%）と梗塞群（6例，8.3\%）の間で出現頻度 に差はみられなかった。CCA は発症後 3 年以降に出現 し, 特に 7 年以降には高頻度にみられ，その程度も高 度であった。病巣部位との関連について, 出血群では 明らかではなかったが, 被殼出血では内包を含む病変 による皮質橋小脳路の順行性変性が考慮され, 視床出 血では小脳赤核視床路の逆行性変性が推測された。梗 塞群においては, 前頭葉, 側頭葉, 頭頂葉を含み放射 冠・内包に及ぶ広範な病変例で CCA を認めやすく, 多 変量解析の結果, CCA の発現には特に頭頂葉や前頭葉 の障害がより強く関与していることが示唆された。ま た同時に, 病側視床の萎縮が確認されることが多く, 直接障害を受けた病変による皮質橋小脳路の順行性変 性とともに，二次的に出現する視床の変性から小脳赤 核視床路の逆行性変性が加わっている可能性も考慮す
る必要があると考えられた。

結語：脳血管障害に続発する CCA は，慢性期にお いては必ずしも稀な変化ではなく，その発現には主と して皮質橋小脳路の順行性変性が推測されたが，一部 小脳赤核視床路を介した逆行性変性の関与も示唆され た，慢性期脳血管障害の臨床に際しては，遠隔領域に みられる二次変性, 萎縮についても留意する必要があ る.

\section{6. 剖検からみた老年者脳出血の検討} 成田記念病院神経内科 川畑信也

目的：脳出血後遺症を有する老年者を対象に剖検か らみた老年者脳出血の病態について検討した。

方法：対象は連続剖検 1,005 例中死亡時年龄が70歳 以上の脳出血患者73名である。これらを対象に部位別 出現頻度や発症年㱓, 日常生活動作 ADL, 死因につい て検討した。

結果：対象の死亡時平均年齢は $81.8 \pm 6.0$ 歳であっ た.病理学的に確認できた脳出血巣は延べ85個であり, 視床 $34.1 \%$, 被殼 $24.7 \%$, 皮質下 $15.3 \%$, 小脳 $14.0 \%$, 混合型 $7.1 \%$, 尾状核 $2.4 \%$, 橋 $1.2 \%$, 脳幹（広範囲） $1.2 \%$ であった。 67 例で「ベッド上の生活」（歩行不能 であるがベッド上にて自力で食事や洗面が可能な者十 寝たきりで全介助）となった年齢は62歳から92歳の間 に分布し平均79.5 5 5.9歳であった。 75 79歳で「ベッ ド上の生活」となる割合が最も高く22例 $(32.8 \%)$ に 及んでいた。脳出血発作を契機として「ベッド上の生

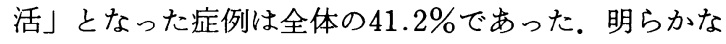
きっかけを確認できず緩徐・進行性に歩行困難をきた し「ベッド上の生活」となった症例は 9 例であった. 一方，入院まで歩行可能であったが，入院後の持続点 滴の開始などが契機となって ADL の低下した症例は 7 例であった。 以下, 脳血管障害再発と大腿骨頸部骨 折各 5 例, 転倒後 4 例, 自発性の減退による歩かない 3 例の順であった，日常生活全てにわたって全介助を 要する寝たきりとなった年齢は70歳から94歳までの間 に分布し平均 $80.8 \pm 5.6$ 歳であった. $76.1 \%$ 症例が寝 たきりとなってから 1 年以内に死亡していた。

結論：「ベッド上の生活」となる契機では潜在性・ 緩徐に進行する筋力低下や自発性・意欲の減退などの 機能的背景が重要と考兄られた。全介助を要する漫た きりとなった時期から 1 年以内に死亡した症例は $76.1 \%$ に及び，老年者では㾛たきりとなることが 1 年 後の生命予後を示唆する要因であることが判明した。 


\section{7．脳血管障害患者の追跡調査}

国立仙台病院神経内科

阿部 憲男

目的：最近变化しつつある脳血管障害患者の長期予 後の実態を検討するために退院後の状況について追跡 調査を施行し，特に老年者についてその動向を検討し た.

対象と方法：対象は昭和 54 年から平成 1 年をで当科 に入退院した脳血管障害患者連続316名で, 平均年齢は 65歳で，65歳未満 (対照群) は145名, 65歳以上 (老年 群)は171名であった。診断は全例神経学的所見および CT 所見からなされた。追跡調査は診療録, アンケート および電話による聴取により，追跡率は $97.2 \%$ ，平均 追跡期間は48力月であった。

結果：退院時の日常生活動作（ADL）は対照群では 日常生活に支障のない典（I）が43\%, 身の回りだけ は一人でできる群（II） $35 \%$, 立ち居に介助を要する 群 (III) $12 \%$, 寝たきり群 (IV) $6 \%$, 死亡群 (D) $4 \%$ であったが老年群では I 群 $28 \%$, II 群 $30 \%$, III群 $16 \%$, IV群 $14 \%, \mathrm{D}$ 群 $12 \%$ と重症群の占める割合が多かった。 追跡時の ADL は退院時と比べ対照群では不変が 66\%, 改善 $11 \%$, 悪化 $23 \%$ (死亡 $9 \%$ ) であるのに対 し老年群ではそれぞれ $52 \% ， 6 \% ， 46 \% （ 33 \% ）$ と悪 化する割合が多かった。 平均在院日数は全体で退院時 ADL が I 群では37日, II群57日, III群100日, IV群 171 日で, 重症群では対照群に比べ老年群で長かった。追 跡期間中の再発は対照群が $20 \%$, 老年群は $16 \%$ で, 再 発例の $65 \%$ でADL の悪化をみた。追跡時死亡例の入 院時から死亡までの期間は対照群で33カ月, 老年群で 32力月と差がなかったが, IV群では死亡をでの期間が 23 月と短かく, 死因の $90 \%$ が脳血管障害そのもので あった。

結論：脳血管障害患者の予後は老年者では ADL が 重症化し，その後の経過でも悪化する割合が多かった。 退院時の ADL が重症なものほどそのまま脳血管障害 が死因として占める割合が多かった。

\section{8. 痙攀発作で発症する脳卒中一加齢との関係一} 秋田県立脳血管研究センター神経内科

$\begin{array}{lrr}\text { 平田 } & \text { 温, 長田 } \text { 乾 } \\ \text { 佐藤 } & \text { 雄一, 高田 博仁 }\end{array}$

目的：脳卒中は高齢者痤攣発作の主因の一つであ る. 脳卒中発作 2 週間以内に生じた痤攣発作を early seizure，それ以降のものを late seizure とすると, 前 者は発症 3 日以内が多く，また後者は高齢者に多いと
いう，今回我々は，脳卒中に関わる痙攣発作と加齢々 の関係を知る目的で，痙攣発作で発症する脳卒中を取 り上げ，検討した。

対象と方法：1985年から1989年まで新たに脳卒中を 発症し入院した脳梗塞723例, 脳出血137例, 計860例の らち, 痤攣発作で発症した 8 例を対象とした。なお, くも膜下出血は集計の都合で今回の対象から除外し た. 脳出血の診断は入院時の頭部 CT で行い, 脳梗塞 は CT 上の低吸収域の経時的変化で診断した． 8 例の 内訳は脳梗塞 4 例, 脳出血 4 例で，年齢は52歳から 80 歳, 平均 67.8 歳であった。本対象例を 70 歳以上の高齢 (O) 群 4 例と, 70 歳未満の非高齢 (N) 群 4 例に分け, 病変部位, 発作症状, 合併症, 転㷌などにつき加齢と の関係を検討した。

結果：脳梗塞は全例左中大脳動脈皮質枝領域に陳旧 梗塞があり，らち 3 例は embolism で前頭葉を含む皮 質梗塞で痤攣発作を発症した。脳出血は 4 例全て皮質 下出血で, $\mathrm{N}$ 群 2 例はともに左前頭極に, $\mathrm{O}$ 群 2 例は 左側頭葉および右頭頂葉に血腫を認めた。痙攣発作は 全例強直間代性の全般発作を呈し, $\mathrm{O}$ 群の脳出血 2 例 は部分発作からの進展, $\mathrm{N}$ 群の梗塞 1 例は後に Jacksonian seizure を発症した。痤攣重積は 4 例に認めた。 脳梗塞の $\mathrm{O}$ 群 2 例とも late seizure の既往があるが, $\mathrm{N}$ 群では初めての疰攣発作で脳梗塞を再発した. 高血 圧の合併は 7 例と多く，また脳卒中の既往が 6 例と多 数を占めた. $\mathrm{N}$ 群では 3 例で注ぼ症状を残さず回復し たが，O 群では 4 例中痴呆が 3 例，5ち 1 例は失外套 状態に移行するなど，予後不良であった。

考察：脳卒中の既往のある老年者の痙攣発作では, late seizure か脳卒中再発か鑑別する必要があり, CT などの画像診断が重要である.

\section{9. 老年者の延髄外側症候群}

都老人医療センター神経内科

山田 滋雄, 名倉 博史 山之内 博, 豊倉 康夫

三重大神経内科 葛原 茂樹

老年者の Wallenberg 症候群の報告例は比較的少な い. その老年者に扣ける特徵を知るため, 当科入院例 のうち, 発症時年龄が 60 歳以上であった 8 例(男 5 例, 女 3 例, 平均 70.3 歳) について検討した。

比較的若い 5 例はすべて男性で左側の病変を有し, 高齢の 3 例は全例が女性で右側の病变であった。高血 圧が 7 例, 糖尿病が 3 例, 心房細動が 1 例にみられ, 
全例が何かの危険因子を有していた。臨床症状, 検査 等から， 1 例が脳塞栓， 7 例が脳血栓と考兄られた。 動脈が検索された症例全例で, 病巣側の椎骨動脈閉塞 が認められた。

4 例が起床時に発見されたが, 他例では発症時刻, 発症時の身体活動とも多様だった。初発症状は, 悪心 3 例, めまい 2 例の他, 麻疸で発症したものが 2 例あ り注目された，症状の完成までに, 大多数が 1 日から 数日を要していた。

症状, 神経学的所見を既報告例と比較した経過, 老 年者においても解離性感覚障害, 嚥下障害, ふららつき が三大症状である点が共通していた。老年者では, 自 覚症状である, めまい, 呕吐, 頭痛, 吃逆が出現しに くく, 逆に, 意識障害や, 片マヒ, 顔面神経マヒの出 現頻度が高かった。䎥下困難は全例とも20日から6 月で十分な経口摂取が可能となっていたが, 構音障害 のある例で回復が遅れる傾向があった，又, 解離性感 覚障害は，60歳台では全例とも早川の I 型であったの に対し，70歳台では，全例とも早川のII型であった点 が注目された。 以上から，(1)老年者は自覚症状のめま い, 頭痛, 呕吐を呈しにくく, 逆に, 意識障害, 片マ ヒ, 顔面神経マヒの合併が多い. (2)70歳台では, 女性 例, 早川のII型が多い. (3)老年者に沶いても, 椎骨動 脈の閉塞によるものが多い, 又, 症状の完成までに数 日を要するものがある，と結論した。

\section{0. 脳血管障害と涙}

埼玉医大神経内科 ${ }^{1)}$, 短期大学 ${ }^{21}$

田村直(俊)21 島津 邦男 ${ }^{11}$ 山元 敏正 ${ }^{11}$ 中里 良彦吕坂西か㧊り ${ }^{11}$ 濱口 勝彦 ${ }^{11}$

淚液量では副交感神経機能を反映すると考兄られ る.脳血管障害 (CVD) では自律神経障害を生じるこ とが知られているが，本症に扔いて涙液量を検討した 報告はない。本研究では, CVD 急性期の涙液量を経時 的に測定した.

対象・方法：半球性 CVD 30例（平均年齢67.3 99.4 歳; mean $\pm \mathrm{SD})$, 対照14例 $(71.4 \pm 10.7$ 歳 $)$ といて, 微量水分測定器 (ペリオトロン; Harco Electronics) を用い, 下眼䀫結膜の貯留涙液量, 反射性分泌涙液量 を測定した。CVDは発症 7 日以内 (I 群：18例, 発症

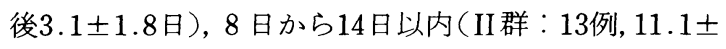

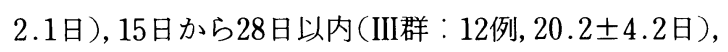
29 日以上の症例（IV群：14例, $40.4 \pm 10.8$ 日）の 4 群 に分けて検討した。
結果：(1) CVD-I 群：貯留涙液量は麻痺側18.5土 13.9 units で, 健側 $29.2 \pm 13.8$, 対照 $21.1 \pm 6.8$ に比し 有意に低值であった $(\mathrm{p}<0.02,0.05)$. 反射性分泌量 も麻瘏側 $33.0 \pm 15.4$, 健側 $50.7 \pm 19.5$, 対照 $56.5 \pm 13.8$ と, 麻盘側で健側, 対照に比し有意に低值を示した ( $<<0.005,0.0001)$. (2) CVD-II 群：眝留涙液量は麻 瘏側 $52.5 \pm 56.8$, 健側 $42.7 \pm 41.5$, 反射性分泌量は各 $74.3 \pm 53.5,70.2 \pm 47.5$ と，いずれも対照に比し異常 高值を示す症例がみられた。（3）CVD-III 群：貯留涙 液量は麻疩側 $31.1 \pm 23.7$, 健側 $23.5 \pm 8.5$, 反射性分泌 量は56.9 $535.1 ， 67.5 \pm 27.7$ と，いずれも正常值に復 する傾向を示した。（4）CVD-IV 群：貯留涙液量は麻 瘏側 $36.4 \pm 16.7$, 健側 $27.0 \pm 11.8 て ゙$, 麻痺側は対照に 比乙有意に高值 $(\mathrm{p}<0.01)$, 反射性分泌量は麻痖側 $73.8 \pm 32.6$, 健側 $61.9 \pm 18.2 て ゙$, 麻㿁側は対照に比し 高値傾向であった $(\mathrm{p}<0.1)$.

結論：CVD，とくにその急性期には涙液分泌の異常 がみられ，涙腺を支配する副交感神経系の障害を示唆 する.

\section{1. 脳血管障害による身体知覚の消去現象の臨床 的意義について}

国立療養所福岡東病院脳卒中センター

田川 皓一, 岩瀬 晶子
大西 昭彦, 飯野 耕三

目的：身体の 2 力所に，同時に同じ性状の知覚が与 えられたとき，一方を認知できない現象を身体知覚の 消去現象と呼ぶ．脳血管障害により出現する本現象の 臨床的意義について検討する。最近では，画像診断の 進歩により, 無症候性, ないしは潜在性の脳梗塞を論 じる機会が多くなっており，特に目立たない症状とし ての本現象に注目したい。

方法：身体知覚の消去現象を呈した33例の脳血管障 害者を対象として, 大脳優位性や消去現象の持続期間, 随半症状, X 線 CT による病巣の広がりを分析した。 さらに本現象の発現機序や責任病巣を検討し，その臨 㦿的意義について考察した。

結果：対象を病型別にみると，30例は脳梗塞で， 3 例は脳出血であった。脳梗塞で病巣をみると，25例は 右半球に, 5 例は左半球に存在した. 左半球損傷の 5 例中 4 例は左利きであった。したがって，30例中29例 は劣位半球の損傷であった。身体知覚の消去現象の持 続期間をみると， 26例は永続し， 4 例は一過性であっ た。 X 線 CT で病巣をみると，本現象が持続した 26 例 
では, 全例で頭頂葉を含む病巣を認めた。一過性であっ た 4 例では， 3 例で病巣の主座は前頭葉にあり， 1 例 で頭頂葉皮質下にあった。頭頂葉損傷をみる症例の多 くは半側空間失認をともなっていた。 その後の経過を みると, 7 例では半側空間失認や要素的な運動・感覚 障害が目立たなくなり，本現象が劣位半球の頭頂葉損 傷として観察される重要な症状となった。なお，脳梗 塞に出現する場合と区別できない本現象が脳出血では 3 例で観察している。全例劣位側の障害であり， 2 例 は視床，1例は被殸出血であった。

結論：本現象は劣位半球頭頂葉損傷の存在を示唆す る徵候であるが，皮質下損傷でも出現しうる徵候であ る. 本現象は劣位半球頭頂葉損傷では永続する徵候で あり, 時には他の随半症状が消失した後す観察するこ とができ，臨床の場では目立たない潜在性の徴候であ る.

\section{2. 初診時高血圧重症度からみた老年者高血圧の} 予後

和歌山県立医大循環器内科

秋津 壽男, 有田 幹雄, 羽野 卓三

福田 和也, 上野 雄二, 西尾一郎

増山 善明

目的：老年者の高血圧は，非老年と比較し，治療予 後の面で異なるとされている，老年者高血圧による合 併症の発症と死亡の特徵を見るため, 当科高血圧外来 患者の予後調査を行ない, 初診時高血圧重症度により 検討した。

結果：最近 16 年間に当科外来を受診または入院し， 以後 3 カ月以上継続して外来受診した本態性高血圧患 者873例を対象にアンケート方式に上る予後調查を行 ない, 初診時の WHO 抢よび東大 3 内科高血圧重症度 分類を用いた重症度と比較した。対象のらち予後の判 明したものは657例で，判明率は $75 \%$ であり，平均観察 期間は 7.2 年であった。 60 歳以上（老年群）は155例 (23\%，男75例，女 80 例)，60歳未満 (若年群) は 502 例 （77\%，男262例，女 240 例)であった。老年群の全死亡 は32例(21\%)， 万ち心血管系合併症によるものは18例 (56\%), 若年者群ではそれぞれ30例 ( $6 \%$ ), 11例(37\%) であった，総死亡は老年群で高かったが，心血管系合 併症の占める割合には差がなかった。老年者の初診時 $\mathrm{WHO}$ 病期分類別, 東大 3 内科重症度指数別にみると, ともに重症例ほど死亡率が高く，心血管系合併症が多 かった。東大 3 内科高血圧症重症度分類の血圧 $(\mathrm{P})$,
脳 $(\mathrm{B})$, 心 $(\mathrm{H})$, 腎 $(\mathrm{K})$, 眼底 $(\mathrm{F})$ 各スコア別に合 併症の発生頻度を見ると，B，H，K の高い例に心血管 系合併症が多く発生し，予後も不良であった。しかし $\mathrm{B}$ と脳合併症, $\mathrm{H}$ と心合併症の発症の間には関連を認 めなかった。东た B-0でも $22 \%$ 死亡があった。

考察と結論：老年者高血圧患者の予後は, 若年者に 比し死亡率は高いが，その中に占める心血管系合併症 の割合には差がなかった。老年者初診時 WHO 病期分 類別，東大 3 内科重症度指数別にみると，ともに重症 ほど予後が悪く心血管系合併症の発症が多かった。初 診時の血圧・臟器重症度別にみると, 脳, 心, 腎の重 症度が高いと予後が悪いが, 藏器スコアとその藏器の 合併症発症の間の関連はなかった。

\section{3. 老年者高血圧の血行動態と左室肥大心電図所} 見

\section{伊豆高原ゆらゆらの里診療所 寺沢富士夫} 浴風会病院鈴木 孝臣, 関 増爾

目的：老年者高血圧症の血行動態と左室肥大心電図 所見との関係に就てのわが国の報告では僅かに佐藤ら （1977年）の報告があるに過ぎない，我々も同じ頃，上 述の点について検討を行なったので少し古いデータ （1972年）であるが発表する。

対象ならびに方法：浴風会病院において平均年齢 80 歳の ADL 正常な女性老年者64例を 5 群に分け，血圧 正常, 心電図正常18例 ( $\mathrm{N}$ 群), 高血圧者 (収縮期血圧 $160 \mathrm{mmHg}$ 以上，抎張期血圧 $90 \mathrm{mmHg}$ 以上のいずれ か，またはその一方を満たすわの）46例を日本循環器 管理協議会分類に準じて，心電図変化無きか軽微な I 群 (21例)，軽度なII群（21例)，中等度III群（9 例), 高度IV群 ( 7 例) について Evans-Blue を用いた色素希 䣋法で血行動態を測定し各群で比較した。

成績：（1）平均血圧： $N$ 群に対し高血圧各群では いずれも有意であったが，後者でも I 群とII群，II群 とIII群の間に有意差を以って上昇し，IV群においては II, III群に比し有意に減少していた（ $\mathrm{N}$ 群に対しては 有意に高値)。(2) 心拍数： $\mathrm{N}$ 群, 高血圧各群間のいず れにも有意差を認めなかった。（3）心係数：N 群に比 し高血圧 I 群で低下傾向を認めたが，III群で上昇しIV 群で低下した。 $\mathrm{N}$ 群とIV群の間には有意差を似てIV群 で低下していた（4）一回心拍出係数：高血圧 I 群よ りIII群にかけて上昇し(I 群とIII群間有意)，IV群では 減少した。（5）心仕事量：I 群よりIII群にかけて上昇 しIV群で低下した。一回心仕事量：N 群に較べ高血圧 
I 〜 III群で上昇（N 群とII, III群間有意, I 群とII, III群間有意）し，IV群で下降した。（6）全末梢血管抵 抗： $\mathrm{N}$ 群に較べ高血圧群で高值を示したが, 特にII群 で高かった。

結論：老年者高血圧群では，左室肥大心電図所見が 中等度迄は平均血圧の上昇に伴って心係数, 一回心拍 出係数, 心仕事量, 一回心仕事量は増加した。心電図 変化高度になると平均血圧の低下と共に心係数は $\mathrm{N}$ 群より低值を示した。

\section{4. 高齢者高血圧患者の心形態変化}

\section{帝京大第三内科}

高岡 典子, 諸岡 茂, 稲垣 雅行

吉田 秀夫, 宿谷 正毅, 道場 信孝

目的：降圧薬にて治療を受けている60歳以上の本態 性高血圧症患者の, 心の形態と機能の経時的変化を, retrospective に検討した。

対象と方法：当院内科外来で 2 年以上継続して薬物 治療を受けている, 60歳以上の本態性高血圧症患者(男 7 例, 女 10 例, 平均年齢 $69 \pm 8$ 歳)について，心ェコー 所見による心の形態と機能の経時的変化を,随時血圧, 心電困，胸部 X 線所見とあわせて検討した。

結果：全体に関する観察期 (平均 30 力月) 前後の比 較では, 随時血圧165/93から148/84mmHg, 心拍数70 から63拍/ $/ \mathrm{min}$, 左房径33から $38 \mathrm{~mm}$, 壁ストレス92か $569 \times 10^{3} \mathrm{dynes} / \mathrm{cm}^{2}$ と有意に変化したが, 左室径, 心 係数, 駆出分画, 壁厚, 後壁払張速度などには有意の 変化はみられなかった。次に, 観察前で, 拡張期左室 径が50mm 以下のものを正常群, $50 \mathrm{~mm}$ をこえるもの を拡大群と分類し比較した。観察期前後とも，体重は 拡大群で有意に大きく, 随時血圧も払大群が高い傾向 を示した，拡張期左室径は，正常群で45から $48 \mathrm{~mm}$ 一 と有意に増加, 拡大群では57から52mm と有意に減 少した。拡大群では收縮期左室径も有意に減少した。 左房径は両群とも増大した。駆出分画は, 正常群65か ら69\%, 拡大群56から60\%で有意な变化ではなかった。 観察前で, 心筋重量係数, 壁ストレスは拡大群で有意 に大であったが，後には改善され，心筋重量係数に招 いては正常群との有意差は認められなくなった。胸部 X 線での CTR と心面積, BUN, 血清 Cr は両群間に有 意差なく, 変化もなかった。 心電図電位では, 拡大群 が正常群に比し観察期前後とも高電位を示した。治療 内容では, 降圧利尿剂の使用が, 正常群で無く拡大群 で 4 例にあった他は薬剤の種類, 使用数に差はなかっ
た。

結論：高齢者高血圧症患者で左室拡大を示す群で は，降圧とともに機能と形態の改善がみられたが，左 室径正常群では加齢の影響を示唆する变化が観察され た。

\section{5. 老年者高血圧患者における降圧薬治療の心肥 大および心機能に及ぼす効果}

東大阪市立東病院

永野 典子，岩坪 晴彦，波多 丈 大阪大老年病医学

\section{三上 洋, 荻原 俊男}

目的：老年者高血圧患者における心肥大の発症因子 としては，高血圧だけでなく加齢による様々な要因が 考兄られ, 降圧薬治療の心肥大退縮効果が若年者之は 異なることが考えられるが，これまでに報告は少ない。 今回，老年者高血圧患者に扔いて降圧薬(Ca 拮抗薬ま たは変換酵素阻害薬）治療の心肥大退縮効果および心 機能に対する効果を検討した。

方法：心ェコー検査にて心肥大を認めた 65 歳から79 歳の老年者高血圧患者 24 人（平均年齢71士1歳）を対 象とした。本態性高血圧患者（収縮期血圧 $\geqq 160$ $\mathrm{mmHg}$, 拡張期血圧 $>90 \mathrm{mmHg}$ ) 13 人と, 収縮期高血 圧患者（収縮期血圧 $\geqq 160 \mathrm{mmHg}$ ，払張期血圧 $\leqq 90$ $\mathrm{mmHg}) 11$ 人の二群において, Ca 拮抗薬または变換酵 素阻害薬を 3 力月間投与した。 2 週間毎に血圧を測定 し, 治療前後で心ェコ一検査を施行, 左室心筋重量 (LVMI) を評価し駆出分画 $(\mathrm{EF})$ を用いて心収縮能を 検討した。

結果：本態性高血圧群（平均年齢70 1 歳）では, 治療前後において収縮期血圧 $174 \pm 3 \mathrm{mmHg}$ から $144 \pm$ $5 \mathrm{mmHg}$, 拡張期血圧 $97 \pm 1 \mathrm{mmHg}$ から $84 \pm 2 \mathrm{mmHg}$ と下降し, LVMI は204 $\pm 14 \mathrm{~g} / \mathrm{m}^{2}$ から $174 \pm 16 \mathrm{~g} / \mathrm{m}^{2}$ と 有意に減少したが， $\mathrm{EF} は 67 \pm 3 \%$ 有意な変化を認めなかった。 又, 収縮期高血圧群（平 均年齢74 2 歳）では，治療前後において収縮期血圧 $167 \pm 3 \mathrm{mmHg}$ から $144 \pm 4 \mathrm{mmHg}$ ，拡張期血圧 $82 \pm 2$ $\mathrm{mmHg}$ から $74 \pm 2 \mathrm{mmHg}$ と下降し, LVMI は $179 \pm 14$ $\mathrm{g} / \mathrm{m}^{2}$ から $156 \pm 12 \mathrm{~g} / \mathrm{m}^{2}$ と有意に减少したが， EFは $77 \pm 1 \%$ か $75 \pm 3 \%$ とこも有意な変化は認めな かった。

結論：心肥大を合併する老年者高血圧患者に颃い て,Ca 拮抗薬または变換酵素阻害薬による降圧薬治療 は, 本態性高血圧症, 収縮期高血圧症ともに心機能を 
低下させることなく心肥大退縮効果を示した.

326. ヒト脳底動脈における加龄にともなう形態計 測学的変化

兵庫医大法医学, 衛生学 ${ }^{11}$, 第二内科 ${ }^{2)}$

羽竹 勝彦, 若林 一郎 ${ }^{1)}$ 垣下 榮三2) 永井 清保2) 菱田 繁

血管に敃いて, 加齢により内膜の肥厚とともに動脈 硬化が進展し，その病理学的変化もよく検討されてい る。しかし，形態計測学的な観点からの報告は少ない。 今回, 我々はヒ卜脳底動脈に打いて, 形態計測学的な 点から加柃にともなら变化について検討した。

実験方法：剖検時に得られた脳底動脈をホルマリン 固定後, 中央部を切り出し，そのパラフィン切片標本 を Elastica van Gieson 染色し, image analyzer sys tem (Quantiment 720, Cambridge Instrument)を用 い, 内弾性板の長さ (IEL), 内膜の面積 (I), 中膜の 面積（M）を測定した。これらの測定値から血管を円 形にたとえて, Fernie および Cook らの方法により内 弾性板までの半径 $(\mathrm{R})$, 中膜の厚さ $(\mathrm{T})$, 内膜の肥厚 率(intimal index, I.I)を次式により求めた。 $\mathrm{R}=\mathrm{IEL} /$ $2, \mathrm{~T}=-\mathrm{R}+\sqrt{\mathrm{R}^{2}+(\mathrm{M} / \boldsymbol{\pi})}, \mathrm{I} . \mathrm{I}=\mathrm{I} /\left(\mathrm{IEL}^{2} / 4 \pi\right)$. また 相対的中膜肥厚率を $\mathrm{T} / \mathrm{R}$ として, 管腔内面積を $\pi \mathrm{R}^{2}-\mathrm{I}$ として求めた。これら各々のパラメーターの相 関を比較検討した。

結果：加齢とともに内膜の面積および内膜の肥厚率 は増加した。しかし，加齢と管腔の面積とは相関しな かった。 内膜の面積の増加とともに相対的中膜の肥厚 率は減少したが内弾性板の長さは増加した。

考察 : 加齢とともに内膜の面積は増加し, 内膜が肥 厚することが確認された。 それにもかかわらず管腔の 面積は加齢とともに減少しなかった。このことは内膜 の面積の増加とともに中膜の肥厚率の减少及び内弾性 板の長さの増加がみられたことから，中膜は相対的に 菲薄化し，血管径が大ききなることによって内膜の肥 厚による管腔の狭窄に対して防御的に作用しているも のと考えられる。

327. 老年者における血清コレステロール值と死因 の分析一第 1 報：心血管疾患死亡について一

都老人医療センター内分泌科

検査科 ${ }^{1)}$, 循環器科 ${ }^{2}$, 健康管理室 ${ }^{3)}$

佐藤 忠弘, 金木 正夫, 荒木 厚

高橋龍太郎, 藤巻 博, 白木 正孝 ${ }^{1)}$
井藤 英喜, 大川真一郎 ${ }^{2}$ 鈴木雄二郎 ${ }^{31}$

目的: 壮年齢層において血清総コレステロール （TC）值は冠動脈疾患, 心血管疾患死亡の危険因子で あることは多くの疫学調査により証明されている。し かし，老年者においてはいまだ明確になっていない。 そこで我々は老年者を対象に血清 TC 值と死因につい て retrospective に調査したので, 今回は心血管疾患 死亡との関係について報告する。

方法と対象：対象は東京都養育院付属の養護老人 ホーム入所者で, 1974年に在籍していた 1,511 名を1989 年まで retrospective に追跡調査したが，生死を確認 出来たのは1,147名であった。生存者は238名, 当セン ターで死亡した剖検例は 533 名であり, 死因と TC 値と の関連の検討には剖検例を用いた。統計学的検討には $\mathrm{t}$-検定，カイ二乗検定を用いた。

結果: 血清 $\mathrm{TC}$ 值の平均は $181.5 \pm 36.6 \mathrm{mg} / \mathrm{d} l$

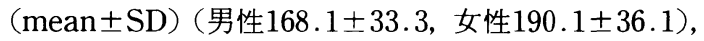
$200 \mathrm{mg} / \mathrm{d} l$ 以上は男性 $17.3 \%$, 女性 $37.8 \%$ であった. 剖 検例の虚血性心疾患 (IHD), 他の心血管疾患 (CVD) および非 CVD 死亡例の TC 值は男性74歳以下でおの

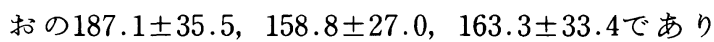
IHD 群で有意に高値であった。男性75歳以上では 3 群 に差は認められなかったが, IHD 群の TC 值は男性74 歳以下群に比し有意に低值であった。女性の TC 值は 74歳以下および75歳以下および75歳以上とも，3 群間 に差は認めなかった。しかし, 高血圧の比率は, IHD 群は他の CVD 群よりも高率であった。 TC 値を200 $\mathrm{mg} / \mathrm{d} l$ 以上，未満に分け，血圧を高血圧，正常血圧に 分けて IHD の発生率 (IHD 死亡/剖検死亡) を比較し たところ, 男性 74 歳以下では TC $200 \mathrm{mg} / \mathrm{d} l$ 以上で, IHD の発生が有意に高率であった。女性74歳以下では TC 別では差がなかったが，血圧別に比較すると高血 圧群に IHD の発生が高率の傾向にあった。

まとめ：血清 TC 值と老年者における心血管疾患死 亡の関係を検討した。74歳以下の男性ではTC值で IHD の発生に差を認めた。しかし, 他の群では差を認 めなかった。

328. 本態性高血圧症患者の食後降圧反応の機序の 解明一若年群と老年群の比較検討（第 2 報）

羽原病院, 大阪大老人科 ${ }^{11}$

多尾 和子, 谷口 和久 ${ }^{11}$ 三上 洋 ${ }^{11}$

羽原 七生, 荻原 俊男 ${ }^{11}$

目的：本態性高血圧症患者, 特に老年者では食後降 
圧反応（postprandial BP reduction）を打こしやすい ことはよく知られている。この食後降圧反応の発現機 序および発現しやすい症例の特性を知る目的で本実験 を行った。

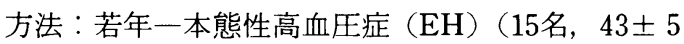
歳), 老年 $\mathrm{EH}$ (13名, $73 \pm 4$ 歳), 若年健常人 (NT) (8 名, $38 \pm 4$ 歳), 老年 NT (11名，74士5 歳)を対象 とし，入院の上 $7 \mathrm{~g} \mathrm{NaCl}$ 食 7 日間摂取後，第 8 日め早 朝安静空腹時および $75 \mathrm{~g}$ Glucouse $225 \mathrm{ml}$ 摄取後 30 分 毎に血圧，脈拍，血浆ノルエピネフリン(PNE)，心エ コーにて心拍出量 $(\mathrm{CO})$, ドップラー法にて腹部大動脈 血流量 (AAo), Ashner 眼球圧迫試験による心拍数の 変動幅を測定. 尚, 食後60分に血圧変動が最も大であっ たため，これらの結果は60分後の値を代表値とした。 第 9 日め早朝安静空腹時に Guanethidine $20 \mathrm{mg}$ 投与, 投与前之後 120 分めに血圧，脈拍，PNE を測定.

結果：平均血圧が $10 \%$ 以上の降圧を食後降圧 $(+)$ とすると老年 $\mathrm{EH}>$ 若年 $\mathrm{EH}>$ 老年 $\mathrm{NT}>$ 若年 NT の 順に高頻度に食後降圧を認めた $(5 / 13 ， 2 / 15 ， 1 / 11$, $0 / 8)$. 老年 $\mathrm{EH}$ 降圧 $(+)$ では CO $\uparrow$, AAo $\uparrow \uparrow$, $\mathrm{PNE} \downarrow \downarrow, \mathrm{A}$ 後 HR $\downarrow \downarrow, \mathrm{G}$ 後 PNE $\downarrow \downarrow$, 老年 $\mathrm{EH}$ 降圧(一)では CO $\uparrow$, AAo $\uparrow, \mathrm{PNE} \uparrow, \mathrm{A}$ 後 HR $\downarrow$, $\mathrm{G}$ 後 PNE $\downarrow \downarrow$, 若年 $\mathrm{EH}$ 降圧 $(+)$ では $\mathrm{CO} \uparrow, \mathrm{AAo}$ $\uparrow, \mathrm{PNE} \searrow, \mathrm{A}$ 後 HR $\downarrow \downarrow, \mathrm{G}$ 後 PNE $\downarrow$, 若年 $\mathrm{EH}$ 降圧(一)では $\mathrm{CO} \uparrow, \mathrm{AAo} \succ, \mathrm{PNE} \uparrow, \mathrm{A}$ 後 $\mathrm{HR} \searrow$, $\mathrm{G}$ 後 PNE $\downarrow$, 老年 NT 降圧 $(-)$ では $\mathrm{CO} \uparrow, \mathrm{AAo}$ $\uparrow, \mathrm{PNE} \uparrow, \mathrm{A}$ 後 HR $\downarrow, \mathrm{G}$ 後 PNE $\downarrow$, 若年 NT 降 圧 $(一)$ では $\mathrm{CO} \uparrow, \mathrm{AAo} \nearrow, \mathrm{PNE} \uparrow \uparrow, \mathrm{A}$ 後 $\mathrm{HR}$ 〉, $\mathrm{G}$ 後 PNE 圧 $(+)>$ 若年 $\mathrm{EH}$ 降圧 $(+)>$ 若年 $\mathrm{EH}$ 降圧 $(-)>$ 老 年 $\mathrm{EH}$ 降圧 $(-)>$ 老年 NT 降圧 $(-)>$ 若年 NT 降圧 （一）の順に高值であった。

結論：以上の結果より，老年本態性高血圧症では食 後の消化管への血液貯留とともに交感神経活動性の異 常反応，副交感神経活動性の亢進が関与して食後降圧 反応を怙こしやすいと考兄られた。

\section{9. 自覚症のない高跉者の Postprandial hypotension $の$ 検討}

榛名荘病院内科 笠原浩一郎，宇都木敏浩 中之沢病院 小松 宗弘 群馬大第二内科 加藤 典弘, 安達 仡 伴野 祥一, 河津 捷二

目的：高齢者にみられる心血管運動調筋異常の一徵
候, Postpradial hypotension の初期状態を知る目的 で，全く自覚症状のない老人ホーム入居者にグルュー 又負荷試験（OGTT）を施行し，検討した。

対象と方法：経費老人ホーム $\mathrm{A}$ 型入居者 32 名（男 2 名, 女 30 名, 平均年齢 $80.9 \pm 2.3$ 歳, 年齢範囲 $72 \sim 92$ 歳) に75g OGTTを施行し, 血圧, 脈拍, 血浆 Glucose, IRI，血浆 Catecholamine 等を測定した。IRIはRIA 法, 血浆 Catecholamine はCOMTを用いた Radioenzymatic methodによった.

結果：Postprandial hypotention は負荷後60分, 120 分のいずれも負荷前に比し血圧低下を示したものを I 群, 負荷後60分のみ血圧低下を示し，120分では負荷前 值に戻ったものをII群, 負荷後120分ではじめて血圧低 下を示したIII群の三群に分けることができた。負荷後 血圧の変化を示さなかったもの, 血圧の軽度上昇を示 したものを正常群とした。

血浆 Glucose より $\operatorname{Normal}(\mathrm{N})$, Imparied Glucose Tolerance (I), Borderline DM (B), DM (D) に分 類すると, 正常群 $(\mathrm{n}=12)$ は $\mathrm{N} 2, \mathrm{I} 5, \mathrm{~B} 4, \mathrm{D} 1$ ， とな り, I 群 $(\mathrm{n}=5)$ は N1, I1, B1, D1, II 群 $(\mathrm{n}=8)$ は N1，I4，B2，D1，III群 $(\mathrm{n}=7)$ は N1, I2, B2, D2 となる。いずれの群も正常群とその分布に差はな く, 群間でも差は認めなかった. I 群は正常群より安静 時血浆 Norepinephrine が有意に低值を示し（332.4 $80.9 \mathrm{SDpg} / \mathrm{m} l \propto 561.0 \pm 103.4 \mathrm{SDpg} / \mathrm{m} l)$, 負荷後 120 分においてもI群は有意に低值であった（433.8 881.1 $\mathrm{SD} \mathrm{pg} / \mathrm{m} l \cos 962.8 \pm 149.5 \mathrm{SD} \mathrm{pg} / \mathrm{m} l)$. 血浆 Epinephrine も負荷後120分でI群；24.0土3.26SD pg/ml と正常群； $66.3 \pm 29.5 \mathrm{SD} \mathrm{pg} / \mathrm{m} l$ より有意に低かっ た。

結論：グルコース負荷試験後, 持続的に低血圧を示 すタイプでは，負荷前より血奨 Norepinephrine の低 下があり, 負荷後も正常より低下傾向を示し, 明らか に交感神経機能の低下が示唆された。

\section{0. 老年者における食後低血圧の病態生理的検討} 都老人医療センター循環器科

$\begin{array}{ccrrr}\text { 下沢 } & \text { 達雄, 桑島 } & \text { 玈, 鈴木 } & \text { 康子 } \\ \text { 星野 } & \text { 智, 金丸 } & \text { 晶子, 坂井 } & \text { 誠 } \\ \text { 松下 } & \text { 哲, 上田 } & \text { 慶二, 蔵本 } & \text { 築 }\end{array}$

目的：老年者における食後低血圧の発症機序を心血 管系, 自律神経系及びホルモン系から解析した。

対象：糖尿病，パーキンンン病，心不全，意識消失 の既往, 明かな自律神経障害, 心機能障害のない老年 
者19名を対象とした.

方法：血圧变動に影響を及ぼす薬物の服用を中止 し，十分日時の経過した後に空腹時に，(1）経口糖75 $\mathrm{g}$ 負荷試験, (2) $200 \mathrm{~m} l$ 飲水負荷試験, (3) 食事負荷試 験（塩分 $2 \mathrm{~g}$, タンパク質 $25 \mathrm{~g}$, 脂肪分 $30 \%$, 炭水化物 45\%）を行った，負荷試験前に30分より座位安静で自 動血圧計にて血圧，脈拍を 15 分おきに負荷後 60 分まで 測定した。また負荷前，負荷後15分，30分，45分，60 分に血糖, インシュリン, 中性脂肪, カテュラミン, レンン活性を測定した。また携帯型自動血圧計による 24時間血圧測定と心電困にて R-R 間隔变動を測定し た。

結果：全例で飲水負荷試験では有意な血圧変動, 血 液データーの変動を認めなかった. 経口糖 $75 \mathrm{~g}$ 負荷, 食 事負荷試験のいずれかで血圧低下を認めたもの（A 群) 14例，いずれでも血圧低下を認めなかったもの（B 群）が 5 例認められた。両群とも年齢および 24 時間の 血圧の平均值に差を認めなかった。 また心拍数, イン スリン值に差はなかったが A 群では負荷後カテュラ ミン, レニン活性値の上昇が B 群に比べ有意に小さ かった。 また負荷前後の血圧の変化度 $(\Delta)$ と $\Delta$ レニン 活性の間には糖負荷, 食事負荷ともに有意な負の相関 が認められた。 $\Delta$ 中性脂肪, $\Delta \mathrm{R}-\mathrm{R}$ 変動には差がみられ なかった。ささらに $\mathrm{A}$ 群では糖負荷及び食事負荷時の血 圧の変化等に有意な正の相関が認められた。

結論：食後低血圧の成因には自律神経系の障害が考 えられるが特にレニン活性の反応が低下していたこと から交感神経障害が重要な役割を果たしていると考兄 られる。また糖負荷による血圧変動と食事負荷による 変動に強い相関が認められたことより糖摂取が食後低 血圧に重要な役割を持つと考学られる。

\section{1. 当科における起立性低血圧の特徵}

和歌山県立医大循環器内科

吉川 博之, 秋津 寿男, 浦 雅子
福田 和也, 有田 幹雄, 上野 雄二
西尾 一郎, 増山 善明

目的：起立性低血圧は，老人に多く種々の成因によ り多彩な病態を示す，当科に入院した起立性低血圧患 者について，起立性低血圧の病型分類，原因疾患，圧 受容体反射弓の障害部位及び加踰による特徵について 検討した.

対象と方法：対象は, 収縮期血圧が $20 \mathrm{mmHg}$ 以上低 下寸る起立性低血压患者15例 (68 43 歳) で, 起立試
験, head-up tilt 試験, Valsalva 試験, 過換気試験, 寒冷昇圧試験, phenylephrine 負荷試験, atropine 負荷 試験, 安静時と立位時の血浆 noradrenaline (PNA) 濃度等を測定し, 病型分類, 圧受容体反射弓の障害部 位別原因疾患を検討した。なお，起立により脈拍数が 20/分以上増加する群を交感神経緊張型, 10/分末満の 群を非交感神経緊張型とした。

結果：起立試験において，起立時の収縮期血圧の下 降度は加龄に従って増大した $(\mathrm{r}=0.74, \mathrm{p}<0.01)$. 起 立試験でみた病型分類では, 非交感神経緊張型 7 例 ( $67 \pm 11$ 歳), 交感神経緊張型 4 例 (71 \pm 8 歳), 分類不 能 4 例であった。交感神経緊張型では, 安静時に比し 立位時の PNA 濃度の上昇が認められたが, 非交感神 経緊張型ではほとんど上昇は認められなかった。原因 疾患は進行性自律神経失調症 4 例 (68 55 歳), 脳血管 障害 1 例 (64歳), 神経梅毒 1 例 (78歳), 循環血液量 の減少 4 例（64 \pm 10 歳, $5 ち 1$ 例は血管反応性の低下 を伴った）であった． 60 歳未満の 3 例中 2 例は血液透 析の患者であった。非交感神経緊張型における圧受容 体反射弓の障害部位は, 中枢 1 例(78歳), 中枢と交感 神経遠心路 2 例 (66 2 歳), 交感神経及び副交感神経 遠心路 3 例（68土12歳）であった。

結論：当科に入院した起立性低血圧患者は, 非交感 神経緊張型が多く,そのらち中枢および遠心路の障害 を示すものが多かった。

\section{2. 動脈硬化と脳血管障害一剖検例よりの検討一 日医大老人科}

$$
\begin{array}{lr}
\text { 大庭 } & \text { 建三, 奥山 裕, 春山 勝 } \\
\text { 武内 寛, 中野 博司, 山下 直博 }
\end{array}
$$

妻鳥 昌平

浴風会病院内科

板垣 晃之, 早川 道夫, 大友 英一

目的：各動脈のアテローム硬化の程度と脳血管障害 との関連を剖検例につき検討した。

対象执よび方法：対象は浴風会老人ホームに在住 し, 死後剖検し得た男女合計 482 例である. 大動脈およ び大腿動脈のアテローム硬化度はその程度により 3 段 階に，脳底部の動脈は 4 段階に分類した。脳病変は約 $1 \mathrm{~cm}$ 毎に連続的に冠状断し, 肉眼的に梗塞巣掞よび出 血巣を確認し，その合併頻度を死亡時の年代別（60, $70,80,90$ 歳代)に各動脈の硬化度別に比較検討した。 脳梗塞巣については, 剖検時に認められた例（脳梗塞 (病理))の中で生前診断されていた例 (脳梗塞 (臨床)) 
の頻度についても検討した.

結果：(1) 大動脈については,いずれの年代群の脳出 血, 脳梗塞 (病理) および脳梗塞（臨㦿）の出現頻度 に動脈硬化の程度別に差はなかった。

(2) 大腿動脈については, 90歳代の脳出血および80歳 代の脳梗塞（病理）に打いて動脈硬化高度例に出現頻 度が有意に高率である以外に差はなかった。

(3) 脳底部の動脈については, 脳出血が80歳代, 脳梗 塞 (病理) および脳梗塞（臨床）が60歳, 70歳, 80歳 代死亡例で, 動脈硬化度が高度になるにつれ有意に高 頻度となった。

結論：脳底部の動脈のアテローム硬化の程度と脳梗 塞病変の間には明らかな相関がみられたが，大動脈お よび大腿動脈のアテローム硬化度と脳出血および脳梗 塞病変, 脳底部の動脈のアテローム硬化度と脳出血病 変との関連は弱かった。

\section{3. 動脈硬化と冠動脈硬化性病変一剖検例よりの} 検討一

\section{日医大老人科}

奥山 裕, 大庭 建三, 春山 勝 大崎良一郎, 中野 博司, 山下 直博 妻鳥 昌平

浴風会病院内科

板垣 晃之, 早川 道夫, 大友 英一

目的：各動脈のアテローム硬化の程度と冠動脈硬化 性病変との関連を剖検例につき検討した。

対象㧍よび方法：対象は浴風会老人ホームに在住 し, 死後剖検し得た男女合計482例である.大動脈拉よ び大腿動脈のアテローム硬化度はその程度により 3 段 階に，脳底部の動脈は 4 段階に分類し，死亡時の年代 別 $(60,70,80,90$ 歳代) に各動脈の硬化度別に心筋 梗塞病変の合併頻度および冠動脈狭窄指数を比較検討 した。, 心筋梗塞病変は肉眼的に確認し, 冠動脈狭窄指 数は内腔狭窄の程度により 0 〜 5 での 6 段階に評価 し， 3 主要枝について各々における最も高度の狭窄部 の点数を合計した，合併頻度は $\chi^{2}$ 検定, 冠動脈狭窄指 数の分布はWilcoxon 順位和検定を行なった.

結果：(1) 心筋梗塞の合併頻度は, 大腿動脈の80歳代 死亡例に抢いて動脈硬化の程度とともに有意に高率と なった以外は, いずれの年代群においても大動脈, 大 腿動脈および脳底部の動脈のアテローム硬化の程度と の間には相関はなかった。

(2) 冠動脈狭窄指数については, 大動脈では60歳, 70
歳および80歳代死亡例，大腿動脈および脳底部の動脈 では70歳および80歳代死亡例で動脈硬化度が高度にな るにつれ，その指数は有意に高値側に分布した。

結論：大動脈，大腿および脳底部の動脈のアテロー 么硬化の程度と冠動脈硬化の程度に明らかな相関がみ られた。

\section{4. 心電図虚血性変化と総頸動脈血流動態の関連} 奈良県立医大第 1 内科

嶋宏子, 澤井 冬樹, 山野繁

小松 正佳, 森岡 泰子, 鶴田 俊介

澤口尚重, 土肥 和紘, 石川 兵衛

目的：安静時心電図におけるST下降の進展度と, 総頸動脈血流動態の関連について検討した。

方法：脳血管障害，糖尿病および不整脈の既往のな い60歳以上の女性51例，男性22例の計73例（平均年齢 71.0 歳)を安静時心電図の ST 所見から, ST 変化を認 めないI 群17例(平均年歯68.5歳), ST 下降が0.04mV 以内の II 群21例 (平均年齢69.1歳), ST下降が $0.05 \sim 0.09 \mathrm{mV}$ のIII群16例 (平均年齢70.8歳), ST下 降が $0.10 \mathrm{mV}$ 以上のIV群 19 例 (平均年歯 75.6 歳)の 4 群 に分けた。総頸動脈血流動態は林電気製 QFM-1000を 用いて右頸䅡動脈の平均血流量（BF），平均血流速度 $(\mathrm{BV})$ ，平均血管径 (VD)，血管壁偏位 $(\Delta \mathrm{D})$ ，循環抵 抗 (Z) 拈よび容積弾性率 (VE) を測定し, 総頸動脈 血流動態の指標とした。

結果：総頸動脈血流動態の指標中, $\Delta \mathrm{D}$ および VE は各群間で明らかな差を認めなかった。 $\mathrm{BF}(\mathrm{ml} / \mathrm{sec})$

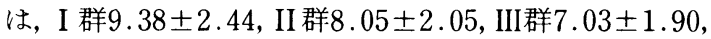
IV群7.04 2 .06であり，III群およびIV群の BF は I 群 に比してそれぞれ有意の減少を示した $(\mathrm{p}<0.01) B V$ $(\mathrm{cm} / \mathrm{sec})$ は, I 群17.75土4.05, II 群16.25土4.31, III 群14.11土4.64, IV群12.15士4.50であり，III群扎よび IV群の BV はI 群と比して，またIV群の BV はII群に 比してそれぞれに有意の減少を示した $(\mathrm{p}<0.05)$. VD

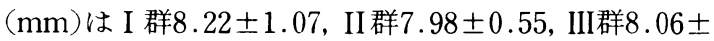

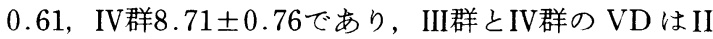
群に比して有意の増加を示した $(\mathrm{p}<0.05) . \mathrm{Z}(\mathrm{mmHg})$

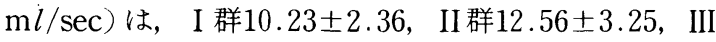

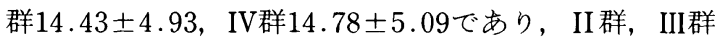
およびIV群の Z はI 群に比して有意の増加を示した $(\mathrm{p}<0.01)$.

総括：総頸動脈血流動態の指標中, 平均血流量, 平 均血流速度, 平均血管径および循環抵抗と安静時心電 
図におけるST 下降の進展度との間に関連が認められ た. 安静時心電図でST 下降を認める症例では, 脳血流 減少に注意する必要がある。

335. 総頸動脈血流速度, 血管内径および血流量の加 齢变化一超音波ドップラー法による検討一

岩手医大神経内科

$$
\begin{array}{llll}
\text { 田村 乾一, 鈴木 } & \text { 一, 川嶋 雅浩 } \\
\text { 石橋 靖宏, 紺野 衆, 平井 和子 } \\
\text { 東儀 英夫 }
\end{array}
$$

目的：虚血性脳血管障害の最大の危険因子は加齢で あるが，その理由は充分に明らかではない，脳血管の 加秢による变化を検討する目的で, 健常者の総頸動脈 の血管内径，血流速度を超音波ドップラ一法により測 定し，血流量などを求め，年齢による变化を検討した。

方法：岩手県大東町検診を受診した健常者61名（男 性23例，女性38例，年齢32 86歳，平均 57.8 歳）を対 象に超音波ドップラー（QFM-2000XA，日本光電）を 用いて, 左総頸動脈の血管内径, 血流速度を測定し, それらより求まる血流量, 循環抵抗, 血管容積弾性率 について，年齢による変化を検討した。

結果：(1) 加龄とともに以下の変化が見られた. 1. 血流速度は低下（特に最大血流速度で有意）２２，血管 内径は増加傾向. 3. 血流量の低下 (特に最大血流量で 有意). 4. 循環抵抗は増加傾向．5. 血管の硬さ (血管 容積弾性率)は有意に増加。6. 血流量の波形の収縮期 の第 1 ピーク F1と第 2 ピーク F2の絶対值を求めてみ ると，第 2 ピークと第 1 ピークの比 $(\mathrm{F} 2 / \mathrm{F} 1)$ は有意に 増加。

（2）血流量に対する血流速度と血管内径の関係は, 若年者では血流量は血流速度に比例したが，高龄者で は血流量は血流速度のみならず, 血管内径にも比例し た.

336. 健常住民における総頸動脈血流速, 血管径, 血 流量, 容積弾性率の加齢变化と危険因子

国立循環器病センター動脈硬化代謝内科

慶応大伊勢慶応病院 ${ }^{1)}$, 埼玉中央病院内科 ${ }^{2)}$

$$
\begin{array}{lrl}
\text { 村上 } & \text { 一雄, 都島 } & \text { 基夫 } \\
\text { 川村 } & \text { 顕 }{ }^{1} \text { 丸山 } & \text { 太郎 }{ }^{21}
\end{array}
$$

目的：動脈硬化性血管障害を予防するため, 動脈硬 化の非侵襲診断の一つとしてドップラーによる総頸動 脈の血流測定を行っている. 本研究はその基礎として, 農村, 漁村の住民を対象に加齢変化々, 粥状硬化のリ スクファクターの影響につき検討した。
方法：対象は, 三重県紀勢町の農村, 漁村に住み, 健康診断に参加して頸動脈血流を測定した男性 127 人, 女性 203 人である。このうち男性 25 人，女性 44 人は 6 力 月ないし 4.5 年の間隔で 2 度以上計測を行った. 頸動脈 血流の測定は，定量的頸動脈血流測定装置 (QFM2000 XA)を用い, 総頸動脈の血管径, 血流速を計測して血 流量を求め, 右上腕血圧を入力することにより容積弾 性率 $\left(\mathrm{V}_{\mathrm{E}}\right)$, 特性弾性系数 $(\boldsymbol{\beta})$ などを算出した。

結果：加龄に伴い, 血管径の拡大 (男性 : $\mathrm{r}=0.249$, $p<0.02$, 女性 $: r=0.207, p<0.05$ ), 血流速の低下 (男 性 : $\mathrm{r}=-0.253, \mathrm{p}<0.02$, 女性 $: \mathrm{r}=-0.184, \mathrm{p}<$ 0.05 ), $\mathrm{V}_{\mathrm{E}}$ の上昇 (男性 : $\mathrm{r}=0.400, \mathrm{p}<0.01$, 女性： $\mathrm{r}=0.351, \mathrm{p}<0.01$ ), $\beta$ の上昇(男性 $: \mathrm{r}=0.466, \mathrm{p}<$ 0.01 , 女性 $: \mathrm{r}=0.322, \mathrm{p}<0.01)$ をみたが, 血流量に は加齢変化はなかった。また $\mathrm{V}_{\mathrm{E}}$ と $\beta$ との間には強い 正相関を認めた $(r=0.887, \mathrm{p}<0.01)$. 高血圧, 肥満 といった危険因子は年齢を補正した 50 歳代の住民で $V_{E}$ に関与していた。 $\beta$ にはこれらの影響はなかった。 血清脂質, 空腹時血糖は $V_{E}, \beta$ とも有意な相関を認め なかった。経年変化をみた症例では $\mathrm{V}_{\mathrm{E}}, \beta$ とも有意な 変化はなかった。

結語：脳血管特性諸計測値のうち, 血管径, 血流速, $\mathrm{V}_{\mathrm{E}}, \beta$ は加龄に伴なう動脈硬化性変化の指標となる が，㤡状硬化性狭窄と関連があるといわれる血流量と 年齢との間には相関はなかった。すた年龄の影響を補 正すれば, $\beta$ は $\mathrm{V}_{\mathrm{E}}$ より血圧などの影響が少なく，血管 壁の加齢変化の有用な指標であることが示唆された。

337. 糖尿病および動脈硬化症における非観血的指 標としての前腕血流量・橈骨動脈血流速度・大動脈脈 波伝播速度・尿中11-dehydro- $\mathbf{T X B}_{2}$

埼玉医大第四内科

赤羽 重樹, 板橋 明
片山 茂裕, 石井 淳

目的：糖尿病と正常者において, 非観血的な方法で 前腕血流量 $(\mathrm{FBF}) \cdot$ 橈骨動脈血流速度 $(\mathrm{RABV}) \cdot 大$ 動脈脈波伝播速度 $(\mathrm{PWV}) \cdot$ thromboxane A2(TXA2) の主たる代謝産物である11-dehydro TXB2(11-DHT) の尿中排泄量 (ng/mg Creatinine) を測定し，それそ れの関連を検討した。

方法：対象は, 糖尿病患者群 $(\mathrm{DM}) 30$ 名, 健常者 $(\mathrm{C})$ 群15名. DM は正常血圧群 (DMNT) および高血圧群 (DMHT ; >160/95mmHg) に分けた. FBF $(\mathrm{ml} / 100$ $\mathrm{ml} / \mathrm{min})$ は, Straingauge plethysmography にて, $\mathrm{RABV}(\mathrm{cm} / \mathrm{sec})$ は超音波ドップラーにてその最大速 
度を求め, $\mathrm{PWV}(\mathrm{m} / \mathrm{sec})$ はトランスデューサーにて 計測した。尿中11-DHT は，RIA 法にて測定した。

結果：(1) PWV は, C 群では50歳未満 $(7.61 \pm 0.53$ ； $\mathrm{SEM})$ に比べ50歳以上 $(11.39 \pm 1.12)$ で高值を示し

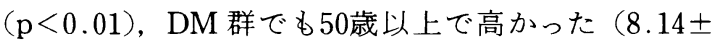
0.87 vs $12.5 \pm 0.76, \mathrm{p}<0.05)$ 。また，PWV と年齢の 間に C 群 $(\mathrm{r}=0.654 ; \mathrm{p}<0.01)$ および DM 群 $(\mathrm{r}=$ $0.410 ； \mathrm{p}<0.05)$ で正の相関を認め，その傾きはそれ ぞれ0.09・0.14であり, DM 群で高かった. (2) FBF は, $\mathrm{C}$ 群で年齢と有意な負の相関を示した。高血圧合併の 有無でみると，C群に比し DMHT で有意に低下して

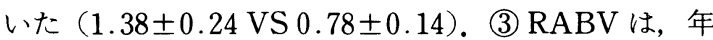
齢・DM の有無・高血圧の有無で，差がなかった。(4) $\mathrm{FBF}$ と RABV の関係は，DM 群で $\mathrm{r}=-0.471 （ \mathrm{p}<$ 0.01）と負の相関が得られた。 (5)尿中11-DHT は C 群 で50歳未満 $(1.10 \pm 0.10)$ に比へ， 50 歳以上 $(2.78 \pm$

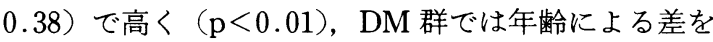
認めなかった。高血圧合併による差は認めなかった。 (6) 50 歳未満 C 群の $\mathrm{PWV}$ の mean $+2 \mathrm{SD}=10.2$ を基準 にすると，11-PHT 排泄量は，10.2以下の群（1.61士 $0.21)$ に比し，10.2以上の群 $(2.79 \pm 0.47)$ で高值で あった $(\mathrm{p}<0.05)$.

結論：PWV・尿中11-DHT は加齢により増加し, PWV 高値の群で尿中11-DHT は有意に高かった。 FBF は，加齢により低下した。末梢血管抵抗の高い群 では，FBF と RABV が負の相関より，FBF は動静脈 の distensibility を表わし, RABV の增加は, 血管内皮 障害につながる可能性が考えられた。

\section{8. 体重変動の身体パラメーターに及ほす影響 一同一個体の経時的変動について}

日医大第二内科

$$
\begin{aligned}
& \text { 大村 直子, 福生 吉裕, 小林 陽二 } \\
& \text { 村松 忠, 永島 幹夫, 神原 礼文 } \\
& \text { 高木 信一, 本田 治久, 荒木 宏 } \\
& \text { 赫彰郎 }
\end{aligned}
$$

目的：肥満は動脈硬化促進の重要な一因子である が，加齢，遺伝的因子のみならず環境的因子により大 きな影響を受ける，八丈島では肥満者は 30 歳以上の島 民の $20 \%$ 以上を占め, 今後老年期疾患発生率の増加が 危惧される，我々は，1985年～1988年に互り住民健康 診断を行なった。 3 年間に追跡調査し得たコホートよ り，同一個体の体重の増減が身体パラメーターにいか なる影響を及ぼすかを男女別に検討した。

対象と方法：1985年～1988に互り継続的に観察し得
た男性53名女性159名を対象とした。1988年平均年齢は 男性60.3歳女性59.18歳であった。各人の BMI を算出 し, 3 年間に 0.5 以上の変動により減少群, 不変群, 増 加群に分けた。次に, $\triangle \mathrm{BMI}$ と各身体パラメーター変 動の相関を男女別に検討した。

結果：男性で肥満者は増加傾向にあり，女性では明 らかな傾向はなかった。女性では, 増加群, 減少群と も男性より高率であった。男女共, $\Delta B M I$ と収縮期・ 拡張期血圧では正の相関を認めた。男性ではUA, HDL で逆相関を認め，女性では TG で相関がみられ たが，UA，HDL との相関関係はなかった。

まとめ：体重増減の身体パラメーターに及ぼす影響 のみならず，体重変動にも性別により差がみられた。 性差は，中高年肥満の身体への影響ばかりか，肥満の 成因にも関与している。 TG, HDL, UA 変動にみられ た性差は，肥満の成因解明の一助となり得る。

339. 体脂肪分布と合併症一超音波診断装置を用い た体脂肪分布の指標（AFI）による検討

千葉大第二内科

渡邊 聡枝, 稲寺 秀邦, 石川 洋 西出 敏雄, 森崎 信尋, 斎藤 康

吉田尚

松戸市立病院

鈴木 良一, 秋山一秀, 大島 仁士 肥満は動脈硬化の危険因子と言われている。近年, 同じ肥満度でもその脂肪が腹壁筋層より内側に多いい わゆる内臓型脂肪分布をとる症例で合併症が多い事が 知られるようになった。すなわち，肥満度だけでなく， 脂肪分布を考慮して個人の理想体重が設定されるべき であると考えられるよらになってきている。そこで 我々は従来 $\mathrm{X}$ 線 CT で行なわれてきた脂肪分布の評 価をより多くの症例で可能とするため，超音波診断装 置を用いた体脂肪分布の推定の指標 (Abdominal wall FAt Index = AFI ) を考案し，CTによる V/S（内臓脂 肪面積/皮下脂肪面積）比と高い相関が得られること を，既に報告した。AFI は上腹部正中綎走查での腹膜 前脂肪の最大厚と皮下脂肪の最小厚の比であり, AFI は内藏型脂肪分布で高值となる。

この AFI を高脂血症・肥満症患者 (82名), 冠動脈造 影施行者 (59名), 人間ドック受診者 (154名) につい て測定し，検討を行った。

BMI 26 以下で糖尿病・高血王・高脂血症・脂肪肝を 有さない症例での AFI の平均値は男性で1.0，女性で 0.7であった。男性で AFI 1.0以上打よび女性で0.7以 
上を高 AFI 群, それ未満を低 AFI 群とすると, 高 AFI 群では低 AFI 群に比べ中性脂肪は高值, HDL コレス テロールは低值であり, 糖尿病・高血圧・脂肪肝の合 併も高頻度であった. $75 \mathrm{~g}$ OGTT 施行時の血浆インス リン面積も高 AFI 群で高值であった。冠動脈造影を施 行した症例において，25\%以上の狭窄を有する症例で は狭窄を有さない症例に比べAFI は高值を示した。

超音波診断装置を用いた体脂肪分布の指標, AFI よ り検討した結果, 内臟型脂肪分布は糖脂質代謝異常と 密接に関連し，さらに冠動脈硬化の危険因子となる可 能性が示唆された。

\section{0. 高齢者肥満症患者の特徵と入院治療の効果に} ついて

\section{東京逓信病院内科}

\section{宮崎 滋, 内藤 周幸}

目的：近年, 高秢者の肥満症患者の増加が注目され ている，我々は高齢者肥満症患者に対して食事療法を 主とした入院治療を行っている，高齢肥満症患者の症 状，合併症，検查成績，治療による体重減少量につい て, 若年者, 中年者を対照として, 高齢肥満症患者の 特徵, 治療に対する反応を比較検討した。

方法：対象は60歳以上の肥満症患者 10 例（男 5 例, 女 5 例), 平均年齢65.8歳 (61歳から75歳), 平均体重 $77.8 \mathrm{~kg}$ (平均男 $83.4 \mathrm{~kg}$, 女 $72.3 \mathrm{~kg}$ ), 平均 BMI 31.5 (最 大 38.2 , 最小 27.5$)$ であり, 全例入院後諸検查を行い, 減食療法の施行が可能であることを確認した後, 超低 エネルギー食 (VLCD)をはじめとする食事制限療法を 行った。 1 日の摂取ェネルギーは400Kcal から800 Kcal とし, 治療期間は症状, 検査成績を検討しながら 2 週間から 4 週間に設定した。

結果 : 入院期間，治療期間に差があるが，入院治療 による体重減少量は, 最大 $17.0 \mathrm{~kg}$, 最小 $3.8 \mathrm{~kg}$ であっ た。 1 日あたりの体重減少量では平均 $210 \mathrm{~g}$ (最大 $340 \mathrm{~g}$, 最小 $110 \mathrm{~g}$ ) であり，40歳以上 60 歳以下の $220 \mathrm{~g}$ と大差な かったが，40歳以下のそれは270g であり, 若年者と比 較すると高龄肥満者では体重減少量がすくなかった。 入院時の合併症の頻度を 60 歳以上と 60 歳未満で比較す ると, 高血圧は 60 歳以上の $40 \%$ に対し 60 歳末満 $21 \%$ で あり，糖尿病は $40 \%$ に対し $22.2 \%$ ，骨関節障害 $40 \%$ に 対し $2.5 \%$, 虚血性心疾患 $30 \%$ に対し $12.3 \%$, 脂肪肝 $30 \%$ に対し $23.4 \%$ ，高脂血症 $20 \%$ に対し $12.3 \%$ と，い ずれも60歳以上の肥満症患者で高値を示した。

結論：60歳以上の高齢肥満症患者では, 治療による 体重減少が小さかった。 その理由は, 高齢肥満者には
合併症が多くみられ，そのため運動療法が十分に行え ず，また食事療法では低ェネルギー食を長期間行らこ とができないことなどにあるのではないかと考えられ た。

341. 肥満は虚血性心疾患の独立した危険因子か？ 一高跉者糖尿病での検討一

千葉大第二内科

森崎 信尋, 渡辺 聡枝, 河野 幹彦

神崎 哲人, 斎藤 康, 吉田 尚

目的：高齢者虚血性心疾患の発症における肥満症の 役割を明らかにする目的で今回は特に糖尿病患者にお いて検討した。

方法：対象は65歳以上の糖尿病患者, 男38名, 女 65 名, 合計103名である. Body Mass Index (BMT) 20, 25を境に瘦せ群, 正常体重群, 肥満群の三群に分類し た。人数はそれぞれ16名，43名，44名であった。統計 的有意差の検定は人数の関係から主として正常体重群 と肥満群間で行った。 虚血性心疾患は心筋梗塞, 狭心 症, それ以外の虚血性心電図異常を含めた。

結果：これら三群での虚血性心疾患の頻度はそれぞ れ19\%，16\%，43\%であり, 肥満症群で有意に高かっ た. 三群間で年齢, 糖尿病の罹病期間, 糖尿病のコン トロール, 治療方法, 高血圧・高脂血症 - 低高比重り ポタンパクコレステロール（低 HDL-C）血症・高尿酸 血症・䒜煙習慣の頻度には推計学的に有意の差はな かった。 しかし, 高血圧, 低 HDL の頻度は肥満群でや や高い傾向を認めた。更に血清脂質のレベルは肥満群 で有意な中性脂肪（TG）の高值, HDL-C の低值が見 られた. BMI と HDL-C との間には負の相関が見られ た。 そこで次に肥満が高血圧, 脂質代謝異常を介して 虚血性心疾患の危険因子となっている可能について検 討した. その結果, 1) 肥満群中では高血圧, 高 TG 血 症, 低 HDL 血症の有無で虚血性心疾患の頻度には有 意な差は無かった。2）肥満群で低 HDL-C 血症, 高 TG 血症のない群を抽出すると, 正常体重群と高血圧 の頻度, 脂質レベルがマッチしたが虚血性心疾患の頻 度はやはり肥満群で有意に高かった。

結論：高路者糖尿病患者では肥満症の存在が, 糖尿 病のコントロールの良否, 合併する高血圧, 脂質代謝 異常などを介さずに虚血性心疾患の危険因子となって いることが推測された。高齢者糖尿病患者の虚血性心 疾患の発症予防には肥満そのものの是正が有効である 可能性が示唆された. 


\section{2. 老年肥満女性の体脂肪分布と糖脂質代謝}

都老人医療センター内分泌科, 検査科 ${ }^{11}$

井上潤一郎，白木 正孝 ${ }^{1)}$ 藤巻 博

高橋龍太郎，井藤 英喜

目的：肥満とは本来, 体脂肪含量 $(\mathrm{F})$ が異常に増加 した状態である。肥満は糖脂質代謝異常の危険因子と されるが，最近，体脂肪分布（FD）の重要性が議論さ れている。そこで, F 及び FD の測定に高い正確性を有 する DUAL PHOTON ABSORPTIOMETRYを用 いて, 老年肥満女性の $\mathrm{F}$ 及び FD と糖脂質代謝との関 連性につき検討した。

対象と方法：対象は老年肥満女性37名（うち糖尿病 27 名) で, 平均年龄 72 歳, 平均身長 $147 \mathrm{~cm}$, 平均体重 62.4 $\mathrm{kg}$ 及び平均体格指数 $29.1 \mathrm{~kg} / \mathrm{m}^{2}$ であった. 糖脂質代謝 の指標として中性脂肪 (TG), 総 (T) コレステロール (C), HDL-C, 早朝空腹時血糖 (FPG) 及び HbAlc を 測定した。体 (B) 脂肪率 $(\% \mathrm{~F})$ を LUNAR 社製 DP. 4により計測した。 $\operatorname{HEAD}(\mathrm{H}), \operatorname{ARMS}(\mathrm{A})$ 及び RIBS を上半身 $(\mathrm{U})$, 残りを下半身 $(\mathrm{L})$ とし, H, A 及び LEGS を末梢部 $(\mathrm{P})$, 残りを体幹部 $(\mathrm{T})$ と定義し, 各部位 の\% $\mathrm{F}$ を算出した. そこで, 各\% $\mathrm{F}$ と糖脂質代謝の各指 標との相関係数を算出した。

結果：TG, TC, HDL-C, FPG 及び HbAlc の平均 值は各々 $157 \mathrm{mg} / \mathrm{d} l, 211 \mathrm{mg} / \mathrm{d} l, 49 \mathrm{mg} / \mathrm{d} l, 151 \mathrm{mg} / \mathrm{d} l$ 及び8.6\%, 平均 B-\%F は $34.3 \%$, U.\%F $30.2 \%, \mathrm{~L}-\%$ F 34.7\%, U-\%F : L-\%F 比87.5\%, T-\%F 35.9\%, P-\%F 31.9\%, T-\%F : P-\%F 比1.15であった。 B-\% $\mathrm{F}$ は FPG及び HbAlc と $\mathrm{r}=-0.371$ 及 び $\mathrm{r}=-$ 0.404 (各々 $\mathrm{p}<0.05$ ), U-\%F はFPG と $\mathrm{r}=-$ $0.402(\mathrm{p}<0.05)$, HbA1c $<\mathrm{r}=-0.432(\mathrm{p}<0.01) の$ 有意な負の相関関係にあった。 L-\%Fは FPG 及び $\mathrm{HbAlc}$ と $\mathrm{r}=-0.356$ 及び $\mathrm{r}=-0.381$ (各々 $\mathrm{p}<0.05$ ) の有意な負の相関にあった。 T-\%Fは FPG及び $\mathrm{HbAlc}$ と $\mathrm{r}=-0.396$ 及び $\mathrm{r}=-0.405$ (各々 $\mathrm{p}<0.05$ ) の有意な負の相関関係にあり, $\mathrm{P}-\% \mathrm{~F}$ と HbAlc とは $\mathrm{r}=-0.369(\mathrm{p}<0.05)$ の負の相関関係にあったものの FPG とは有意の関係は認めなかった。 , 脂質代謝 の各指標は体脂肪分布と有意な関係になかった。

結論：老年肥満女性の体脂肪分布は脂質代謝の指標 とは関連なく, 糖代謝の指標之有意の負の相関関係に あった。特に, 相関関数の值からは下半身より上半身, 末梢部より体幹部の脂肪含量と糖代謝との関連がより 密接であることが示唆された。
343. 肥満の日常生活動作 (ADL) への影響一脳梗塞 発症年齢からの検討

\author{
日医大老人科
}

春山 勝, 武内 寛, 中野 博司

山下 直博, 大庭 建三, 妻鳥 昌平 浴風会病院

板垣 晃之, 早川 道夫, 大友 英一

目的：老年期の肥満が日常生活動作 (ADL) 及び生 命予後に及ぼす影響を脳梗塞症の発症時期別に明らか にする.

方法：対象は浴風会老人ホームに在住し死後剖検し 得た老年者で，剖検所見にて基底核・内包部位に小も しくは中梗塞を認めた男女256例である. 対象を臨床経 過から，何等かの神経学的症状を認めた時期が75歳未 満の症例を老年前期群とし，75歳以上であった群を老 年後期群とした。さらにそれぞれの群を入所時の身長, 体重から，BMI 23.3 以上を肥満群，その他を非肥満群 の計 4 群に分類した. ADL は臨床的に, (1)何等かの神 経症状が認められた後死亡するまでの期間，(2)自力歩 行不能後死亡するまでの期間及び，(3)寝たさりとなり 死亡するまでの期間をそれぞれ Kaplan-Meier 法を用 い検討した。

成績：平均死亡年齢は老年前期群では肥満群 75.6 歳, 非肥満群 74.5 歳, 老年後期群では肥満群 84.7 歳, 非肥満群84.2歳と肥満群で高齢な傾向であった。肥満 が ADL に及ぼす影響については，(1)神経症状が認め られてから死亡するまでの期間は老年前期群では肥満 群で1,700日にかけて非肥満例に比べ有意に長かった が，老年後期群では差はなかった。(2)さらに歩行不能 後死亡するまでの期間はいずれの群も肥満の影響はな かった．(3漫たきりとなってから死亡寸るまでの期間 は老年後期群では肥満群で120日から300日にかけて非 肥満群に比し有意に長かったが, 老年前期群では差は なかった。

結論：老年期の肥満が生体に及ぼす影響を脳梗塞の 発症時期から検討すると, 老年前期群では肥満群で脳 梗塞が早期に認められた。一方，老年後期群では肥満 群で寝たきり状態での生命予後が良好であった。 以上 から老年期の肥満例では平均死亡年龄が高齢であるも のの, 脳梗塞の発症時期別に肥満はADLに対して異 なった影響を及ぼし，機能的な予後は不良であること が示唆された。 